\title{
Putting the 'Public' Back into Public Employment: A Roadmap for Challenging Prior Restraints That Prohibit Government Employees from Speaking to the News Media
}

\section{Frank D. LoMonte*}

\section{INTRODUCTION}

In the weeks following a May 2018 shooting that took ten lives at a high school in Santa Fe, a writer for the New Yorker revisited the Texas community to see how those affected by the tragedy were coping. ${ }^{1}$ One unnamed police officer confided that he'd suffered sleepless nights and been pushed to the edge of "just how much my mind can take" - but readers learned nothing more about him, because, he explained, he was not authorized to talk to the media. ${ }^{2}$

Massachusetts Governor Charlie Baker's administration has made state employees so inaccessible for interviews that one journalist complained he was unable even to speak with a state ornithologist for a routine story about the declining population of barn swallows. ${ }^{3}$ In New York, the director of the New York State Museum retired in frustration over the rigid control of information under Governor Andrew Cuomo's administration, telling a reporter that his staff couldn't even respond to

\footnotetext{
${ }^{*}$ Professor \& Director of the Joseph L. Brechner Center for Freedom of Information at the University of Florida in Gainesville, Florida; B.A., 1992, Political Science, Georgia State University; J.D. (Order of the Coif), 2000, University of Georgia School of Law. The author is grateful to David Jadon for his invaluable research assistance during his time at the University of Florida's Levin School of Law.

1. Carolyn Kormann, Back to School after the Shooting in Santa Fe, NEW YORKER (June 2, 2018), https://www.newyorker.com/news/dispatch/back-to-school-in-santa-fe [https://perma.cc/R9AB-5KKV].

2. Id.

3. David Abel, On Subjects from Birds to Pollution, State Scientists Are Barred from Speaking to the Globe, Bos. GLOBE (May 13, 2019, 6:30 AM), https://www.bostonglobe.com/metro/2019/05/13/frombirds-pollution-state-scientists-are-barred-from-speaking-globe/SN3YSh3FdpOfkG8iD1K1YI/story.html [https://perma.cc/UX2J-UDUC] [hereinafter Abel, On Subjects from Birds to Pollution]; David Abel, A Flap Over Barn Swallows Raises Larger Concerns About a Bird in Decline, Bos. GLOBE (May 11, 2019, 7:06 PM), https://www.bostonglobe.com/metro/2019/05/11/flap-over-barn-swallows-raises-larger-concerns-abo ut-bird-decline/iJpekuqpWejXVG5rCLfvCL/story.html?p1=Article_Inline_Text_Link [https://perma.cc/ZK72-VUB4].
} 
media questions about ladybugs. ${ }^{4}$

"I'm not allowed to talk to the media" is one of the most frustrating responses a journalist can encounter in seeking information from a government agency. Scientists, police officers, teachers, and legislative aides have unique subject-matter expertise, and when they are restrained from sharing their knowledge, the public's understanding of how government operates suffers. As Boston Globe columnist David Abel bemoaned in reporting on the obstacles that journalists encounter in trying to interview state employees in Massachusetts:

For years now, as the environment reporter at the Globe, I have repeatedly requested to speak to a range of state scientists and other officials, hoping they might shed light on the often-complex subjects I write about and answer questions about the state's positions. The response I nearly always receive from the administration-as do many of my colleagues - is a self-serving statement with background bullet points. Rarely do the answers address my questions. ${ }^{5}$

It is accepted almost as a self-evident article of faith that federal, state, and local agencies can prohibit unapproved interactions between employees and the news media. But that assumption rests on an aggressive interpretation of the scope of employer authority in the public sector, one that is irreconcilable with First Amendment doctrine, as well as with sound governance principles in a participatory democracy. To the contrary, policies like those in force in Massachusetts, which require state workers to seek permission from an agency public-relations office before saying anything to a news organization, are almost certainly unlawful.

As Donald Trump assumed the White House during an unusually rancorous transition, concern for the ability of government employees to freely discuss the matters within their expertise gained heightened urgency. News reports that federal scientific agencies had been put on mute - employees banned from giving interviews and from posting to official social-media accounts-provoked alarm that the power of the presidency would be used to silence discussion of global climate change and other issues of public importance. ${ }^{6}$

4. Jon Alexander, State Clamps Down on Release of Information, POST-STAR (Feb. 20, 2013), https://poststar.com/news/local/state-clamps-down-on-release-of-information/article_06338fb27bb6-11e2-9e62-0019bb2963f4.html [https://perma.cc/7XJL-2NMP].

5. Abel, On Subjects from Birds to Pollution, supra note 3.

6. See, e.g., Coral Davenport, Federal Agencies Told to Halt External Communications, N.Y. TIMES (Jan. 25, 2017), https://www.nytimes.com/2017/01/25/us/politics/some-agencies-told-to-haltcommunications-as-trump-administration-moves-in.html [https://perma.cc/LTB9-MA67] (reporting that scientists with the EPA, Interior Department, Department of Agriculture and Department of 
For decades, public employees subjected to blanket gag orders successfully challenged the breadth of those prohibitions and, more often than not, overturned disciplinary actions imposed for "unapproved interviewing." 7 Then came the Supreme Court's 2006 decision in Garcetti v. Ceballos. ${ }^{8}$ Garcetti cast a shadow of uncertainty over the preceding line of cases protecting public employees against discipline for speaking to journalists. Since Garcetti, frontal challenges to workplace gag orders have been rare. Given how deferentially lower courts have applied Garcetti to ratify employer discipline for work-related employee speech, ${ }^{9}$ there is understandable skepticism about whether federal courts' traditional disapproval of broad gag orders is still relevant at all.

Properly understood, Garcetti cannot be read to validate a categorical prohibition on public employees' interactions with journalists. The Supreme Court has said, emphatically, that the core purpose of the First Amendment is to assure "freedom of communication on matters relating to the functioning of government." 10 At most, public employers may enforce tailored prohibitions against, for example, compromising confidential information obtained in the course of employment, or purporting without authority to speak as an official representative of the agency. An unqualified ban on granting interviews, especially when backed up by the threat of adverse personnel action, remains presumptively unconstitutional as a prior restraint on speech, even after Garcetti. $^{11}$

The Supreme Court's 2014 ruling in Lane v. Franks clarified that the Garcetti principle applies to a narrow category of work-assignment speech, vindicating the rights of an Alabama whistleblower fired for testifying unfavorably about his employer before a grand jury. ${ }^{12}$ Since Lane, the one circuit court to address the constitutionality of a gag policy broadly restricting government employees' ability to discuss work-related

Health and Human Services all received memos instructing them not to communicate with the public without supervisory approval, including through interviews or agency social media accounts).

7. See infra Section III.B.

8. 547 U.S. 410 (2006).

9. See David L. Hudson Jr., The Garcetti Effect, ABA J.: NAT'L PULSE (Jan. 1, 2008, 8:14 PM), http://www.abajournal.com/magazine/article/the_garcetti_effect [https://perma.cc/L6LW-D8Q7] (noting that lower courts applying Garcetti "have increasingly ruled against public employee plaintiffs who previously might have won").

10. Richmond Newspapers v. Virginia, 448 U.S. 555, 575 (1980).

11. See United States v. Nat'l Treasury Emps. Union, 513 U.S. 454, 477 (1995) (characterizing restriction on certain federal employees giving public speeches in exchange for honoraria as a prior restraint contravening the employees' First Amendment rights).

12. 573 U.S. 228, 240 (2014) (noting that Garcetti asks "whether the speech at issue is itself ordinarily within the scope of an employee's duties"). 
matters with the public has, properly, struck down the policy as indefensibly broad. ${ }^{13}$

Journalists denied access to their desired government sources should be able to establish standing to challenge unconstitutional gag orders based on their history of success in the analogous context of challenging gag orders on trial participants. ${ }^{14}$ But there is no record of their doing so. Rather, the burden has invariably fallen to government employees penalized for unapproved contact with the news media. As a result, overbroad restraints on employee speech are the Schrödinger's cat of First Amendment law. They are unenforceable constitutionally, yet still proliferate and still exert a powerful influence on the way employees behave-until an employee suffers a serious enough deprivation to motivate a lawsuit.

This Article attempts to provide a roadmap by which news organizations aggrieved by excessively heavy-handed control over public employees' speech can bring their own challenges. It also identifies the likely legal and practical obstacles in litigating First Amendment cases asserting public employees' right to speak freely to the press. Part II lays out the foundational legal principles that constrain the government's authority to prevent or punish speech, and how those constraints are understood to vary in the government workplace. Part III describes how, in a case brought by federal employees denied the ability to earn honoraria for off-hours speaking engagements, the Supreme Court crafted an enduring standard that confines the government's ability to preemptively restrain speech. Part IV explains the Supreme Court's oft-misapplied Garcetti standard, and how widespread misinterpretation of that 2006 decision may have emboldened government employers to enact overreaching speech policies. Part V identifies an additional constitutional infirmity in government agencies' regulation of speech: the failure to enact clear, objective standards constraining the discretion of decision makers in determining who gets to speak. Part VI presents the results of research gathering and analyzing policies to show how routinely agencies at all levels-from Cabinet agencies down to local schools-constrain employee speech in derogation of established First Amendment precedent. Part VII explores why legal challenges to workplace gag orders are rare, and why news organizations can and must assume primary responsibility for bringing the First Amendment cases that employees themselves will not. Finally, Part VIII concludes with a policy-based rationale for unshackling government speakers at a time when struggling news

13. Moonin v. Tice, 868 F.3d 853, 875 (9th Cir. 2017).

14. See infra Section VII.B. 
organizations, and their audiences, need first-hand access to trustworthy information more than ever.

\section{THE FIRST AMENDMENT IN THE GOVERNMENT WORKPLACE}

\section{A. The Tenuous Balance: Authority Versus Individual Liberty}

Outside the employment setting, it is firmly established that government-enforced prohibitions or penalties based on the content of speech are presumptively unconstitutional. ${ }^{15}$ Categorical prohibitions or penalties are vulnerable to constitutional challenge if they are "substantially overbroad," meaning that they are insufficiently tailored to address the government's proffered interest and, consequently, restrict more speech than is necessary to achieve that interest. ${ }^{16}$

"Prior restraints" that categorically forbid speech before it can be heard are especially disfavored, and unlikely to be found lawful absent the most compelling of justifications. ${ }^{17}$ The Supreme Court has long recognized that a government policy forbidding the dissemination of particular speech is a prior restraint. ${ }^{18}$ A prior restraint on speech bears a "heavy presumption against its constitutional validity."19 Indeed, a prior restraint is regarded as "the most serious and the least tolerable infringement on First Amendment rights." 20 Prior restraints are uniquely disfavored because they prevent information from being heard or published at all, and are therefore the most direct attack on the marketplace of ideas. ${ }^{21}$

A century's worth of caselaw establishes that uncensored discussion of governmental affairs is the core of expressive activity the First Amendment is intended to protect. As the Supreme Court stated in

15. R.A.V. v. City of St. Paul, 505 U.S. 377, 382-83 (1992).

16. See Members of City Council of L.A. v. Taxpayers for Vincent, 466 U.S. 789, 798-800 (1984) (explaining that the overbreadth doctrine relaxes traditional standing principles to permit facial challenges to speech-restrictive measures, to prevent "an invalid statute from inhibiting the speech of third parties who are not before the Court").

17. See Bantam Books, Inc. v. Sullivan, 372 U.S. 58, 70 (1963) ("Any system of prior restraints of expression comes to this Court bearing a heavy presumption against its constitutional validity."). Accord Org. for a Better Austin v. Keefe, 402 U.S. 415, 419 (1971).

18. See, e.g., Near v. Minnesota ex rel. Olson, 283 U.S. 697, 723 (1931) (finding that the statute in question operated as a prior restraint that infringed on the freedom of the press).

19. See Sullivan, 372 U.S. at 70. Accord N.Y. Times v. United States, 403 U.S. 713, 714; Keefe, 402 U.S. at 419

20. Neb. Press Ass'n v. Stuart, 427 U.S. 539, 559 (1976).

21. See id. at 559-60; see also Vance v. Universal Amusement Co., 445 U.S. 308, 315-16 (1980) ("[T]he burden of supporting an injunction against a future exhibition is even heavier than the burden of justifying the imposition of a criminal sanction for a past communication."). 
vacating the criminal conviction of a public official charged with defaming local judges: "Truth may not be the subject of either civil or criminal sanctions where discussion of public affairs is concerned .... For speech concerning public affairs is more than self-expression; it is the essence of self-government." 22

The Supreme Court has relaxed the constraints on government authority when the speaker is a public employee. Still, the First Amendment protects public-sector workers, albeit with compromises in the name of workplace harmony and the government's interest in effectively conveying official agency messages. ${ }^{23}$

Public employees retain the right to comment as citizens on matters of public concern. ${ }^{24}$ These interests go to the core of the freedoms the First Amendment was designed to protect. ${ }^{25}$ While the government has special authority to regulate the speech of its employees, "[v]igilance is necessary to ensure that public employers do not use authority over employees to silence discourse, not because it hampers public functions but simply because superiors disagree with the content of employees' speech." 26

A restraint on government employee expression "also imposes a significant burden on the public's right to read and hear what the employees would otherwise have written and said." 27 The Supreme Court has noted that "[g]overnment employees are often in the best position to know what ails the agencies for which they work; public debate may gain much from their informed opinions." 28

In a fragment of dicta with outsized reverberations, thenMassachusetts Supreme Court Justice Oliver Wendell Holmes Jr. wrote in an 1892 retaliatory-discharge case, McAuliffe v. Mayor of New Bedford:

22. Garrison v. Louisiana, 379 U.S. 64, 65-67, 74-75 (1964).

23. See Meyers v. City of Cincinnati, 934 F.2d 726, 730 (6th Cir. 1991) (“[T]o justify a restriction on speech of public concern by a public employee, plaintiff's speech must . . . undermine a legitimate goal or mission of the employer ... or impair harmony among co-workers.").

24. Pickering v. Bd. of Educ., 391 U.S. 563, 568 (1968) (noting that public employers cannot compel public employees "to relinquish the First Amendment rights they would otherwise enjoy as citizens to comment on matters of public interest").

25. See, e.g., Roth v. United States, 354 U.S. 476, 484 (1957) (stating that the First Amendment "was fashioned to assure unfettered interchange of ideas for the bringing about of political and social changes desired by the people"); see also Austin Leland Fleishour, Note, Protecting Harmful Speech on Matters of Public Concern, 79 TENN. L. REV. 213, 217 (2011) ("[T]he Court has furthered the mission of protecting speech on public matters by holding on numerous occasions that expression on public issues has always rested on the highest rung of the hierarchy of First Amendment values.") (internal quotation marks and citation omitted).

26. Rankin v. McPherson, 483 U.S. 378, 384 (1987).

27. United States v. Nat'1 Treasury Emps. Union, 513 U.S. 454, 470 (1995).

28. Waters v. Churchill, 511 U.S. 661, 674 (1994) (citing Pickering, 391 U.S. at 572). 
"[A policeman] may have a constitutional right to talk politics, but he has no constitutional right to be a policeman." 29 For decades, courts declined to entertain retaliation claims by government employees penalized for jobrelated speech. Relying on the Holmes dictum, a New York court in 1950 dismissed a First Amendment challenge to a statute disqualifying members of anti-government organizations from public employment: "A constitutional right of free speech may be abridged as a condition to the enjoyment of public employment. One does not have a constitutional right to be a public employee except upon compliance with reasonable conditions imposed upon all, or imposed under reasonable classifications." 30

The Supreme Court expressly disavowed the Holmes aphorism in a public employee due process case, Garrity v. New Jersey, in which Justice William O. Douglas wrote: "We conclude that policemen, like teachers and lawyers, are not relegated to a watered-down version of constitutional rights." 31 The Supreme Court extended Garrity's reasoning to employee First Amendment claims in Keyishian v. Board of Regents, in which the Court invalidated a New York statute compelling public employees to sign oaths forswearing allegiance to the Communist Party under threat of discharge. ${ }^{32}$

The constitutionality of government constraints on employee speech is analyzed in two different ways, depending on whether the constraint is a blanket prohibition on speech (a "prior restraint") or an after-the-fact punishment imposed for particular speech. ${ }^{33}$ The more commonly litigated scenario is the latter, and consequently, the body of law addressing content-based discipline for speech disagreeable to the employer is the better-known and better-developed.

\section{B. Pickering, Connick, Garcetti, and Content-Based Discipline for Speech}

Just months after its landmark ruling in Keyishian, the Court decided Pickering v. Board of Education and put in place an enduring framework for evaluating the First Amendment claims of public employees punished

29. 29 N.E. 517,517 (Mass. 1892).

30. Lederman v. N.Y. Bd. of Educ., 276 A.D. 527, 528-29, 531 (N.Y. App. Div. 1950) (citations omitted); see also Washington v. Clark, 84 F. Supp. 964, 964-67 (D.D.C. 1949) (dismissing First Amendment challenge to mandatory loyalty oath imposed as precondition of federal employment).

31. 385 U.S. 493, 500 (1967).

32. 385 U.S. 589, 592, 609-10 (1967).

33. See infra Section III.A. 
for the content of their speech. ${ }^{34}$

In Pickering, a public school teacher wrote a letter to a local newspaper critical of his employer's management of money. ${ }^{35}$ In his letter, he addressed the school board's handling of bond issues and the board's "allocation of financial resources between the schools" educational and athletic programs." 36 Pickering signed the letter with his own name. ${ }^{37}$ The school board terminated Pickering for the letter. ${ }^{38}$

Pickering challenged his dismissal as a violation of the First Amendment but found no sympathy in the Illinois courts. The state Supreme Court focused on perceived inaccuracies in Pickering's letter and on the voluntary surrender of freedoms that comes with accepting employment. ${ }^{39}$ The court held:

[A schoolteacher] is no more entitled to harm the schools by speech than by incompetency, cruelty, negligence, immorality, or any other conduct for which there may be no legal sanction. By choosing to teach in the public schools, plaintiff undertook the obligation to refrain from conduct which in the absence of such position he would have an undoubted right to engage in. ${ }^{40}$

The Supreme Court accepted the case and reversed. In an 8-1 opinion by Justice Thurgood Marshall, the justices determined that under the First Amendment, a public employee cannot be terminated for exercising the right to comment on matters of public importance absent proof that the employee knowingly or recklessly made false statements. ${ }^{41}$

The Court acknowledged a government employer's interest in avoiding workplace disruption, but found no evidence of any such disruption resulting from Pickering's letter, which — in Justice Marshall's words - "was greeted by everyone but its main target, the Board, with massive apathy and total disbelief." 42 That the Board might find the letter harmful to members' reputations, Justice Marshall wrote, was not the sort of disruption that could justify restraining or penalizing employee speech. ${ }^{43}$ The Court noted:

\footnotetext{
34. 391 U.S. 563 (1968).

35. Id. at 564 .

36. Id. at 566 .

37. Pickering v. Bd. of Educ., 225 N.E.2d 1, 4 (Ill. 1967), rev'd, 391 U.S. 563 (1968).

38. Pickering, 391 U.S. at 564.

39. Pickering, 225 N.E.2d at 5-6.

40. Id. at 6 .

41. Pickering, 391 U.S. at 574.

42. Id. at 570 .

43. Id. at 571.
} 
The problem in any case is to arrive at a balance between the interests of the teacher, as a citizen, in commenting upon matters of public concern and the interest of the State, as an employer, in promoting the efficiency of the public services it performs through its employees. ${ }^{44}$

Because the lower courts failed to adequately consider the speaker's interest in being heard on a matter of public concern, the justices sent the case back for application of a more speech-protective balance. ${ }^{45}$

The justices added a clarifying, and arguably narrowing, gloss to Pickering in their 1983 ruling in Connick v. Myers. ${ }^{46}$ In Connick, an assistant district attorney, Sheila Myers, circulated a questionnaire among her coworkers about "office transfer policy, office morale, the need for a grievance committee, the level of confidence in supervisors, and whether employees felt pressured to work in political campaigns." ${ }^{47}$ The Court concluded that, with the exception of the question about coercion to volunteer for campaigns, the survey was primarily a series of personal grievances rather than an attempt to inform the public about workplace problems. ${ }^{48}$ The Court's 5-4 majority found it significant that Myers spoke internally within the workplace rather than attempting to convey information to an external audience, which made the survey look like an attempt to "gather ammunition for another round of controversy with her superiors." 49

Because one element of Myers's speech touched on a matter of public concern, the justices proceeded to the second prong of the Pickering analysis, examining whether the survey question jeopardized workplace harmony sufficiently to override Myers's right to speak. ${ }^{50}$ Examining the context and form of the speech, the majority found minimal expressive value and significant risk of workplace disruption: the speech was disseminated at work and not to the larger public, it occurred as a direct outgrowth of Myers's personal dispute with her supervisors over working conditions, and it was likely to prolong and aggravate that dispute. ${ }^{51}$ Thus, it was unprotected. ${ }^{52}$

Justice Byron White's majority opinion repeatedly emphasized the

\footnotetext{
44. Id. at 568 .

45. Id. at $574-75$.

46. 461 U.S. 138 (1983).

47. Id. at 141 .

48. Id. at $148-49$.

49. Id. at 148 .

50. Id. at $150-52$.

51. Id. at $153-54$.

52. Id. at 154 .
} 
narrow fact-specificity of the case, cautioning that the ruling should not be read as a "defeat for the First Amendment." 53 Nevertheless, in the ensuing years, lower courts found in Connick a way to dispose of troublesome cases in which employees ran afoul of their supervisors for speech critical of agency practices or personnel.

For instance, the Fifth Circuit found no First Amendment violation when a Texas college fired a campus police officer over the contents of a personal notepad containing remarks critical of the police chief's management abilities. ${ }^{54}$ The officer, a captain with the University of Houston police department, kept a running log of his perceived shortcomings in department leadership - including inadequately trained supervisors and a lack of exit interviews for departing employees. ${ }^{55} \mathrm{~A}$ copy of the notes were, without his consent, leaked to the chief. ${ }^{56}$ The Fifth Circuit affirmed the trial court's holding that no First Amendment violation occurred, finding that the fired officer "spoke only as an employee and not as a citizen." 57 Similarly, the Eighth Circuit applied Connick to dismiss the First Amendment case of an Arkansas police officer who alleged he was demoted and assigned menial tasks in retaliation for refusing to falsify facts in a statement he was assigned to write concerning the firing of two co-workers. ${ }^{58}$ The court reasoned that, because the officer was speaking in his official capacity in an in-house memo, his speech did not qualify for Pickering protection as the speech of a citizen addressing a matter of public concern. ${ }^{59}$ As one critic stated, reflecting on the first four years of judicial attempts at reconciling Connick with Pickering:

[L]ower federal courts have been anything but consistent in their determination of what speech is protected under Connick v. Myers. Although broad categories of cases can be identified, there exist contradictions within every category, leaving public employees and employers confused as to the scope of their free speech rights and responsibilities. ${ }^{60}$

53. Id.

54. Terrell v. Univ. of Tex. Sys. Police, 792 F.2d 1360, 1361-62 (5th Cir. 1986).

55. Id. at 1361.

56. Id.

57. Id.

58. Buazard v. Meridith, 172 F.3d 546, 547-49 (8th Cir. 1999).

59. Id. at $548-49$.

60. Stephen Allred, From Connick to Confusion: The Struggle to Define Speech on Matters of Public Concern, 64 IND. L.J. 43, 75 (1988); see also Tony Coppola, Note, Content, Form, and Context-The Eighth Circuit Misapplies the Connick Test in Examining the First Amendment Rights 


\section{Constraints on Employee Speech: The Historical Perspective}

It was not until 1925 that the Supreme Court, in Gitlow v. New York, explicitly applied the First Amendment to acts of state and local government constraining speech, by way of the Due Process Clause of the Fourteenth Amendment. ${ }^{61}$ Two decades later, in one of the earliest known challenges to a workplace gag policy, the New York Court of Appeals invalidated a directive by the City of New York Fire Commissioner ordering members of the firefighters' union to stop making disparaging remarks to the news media about their working conditions, under threat of discipline. ${ }^{62}$ The commissioner invoked a department rule providing that employees needed written approval from the chief before their names or images could appear in a newspaper or magazine. ${ }^{63}$ Although the court applied a mere rational-basis level of scrutiny to the regulation and rejected firefighters' facial constitutional challenge, the court found that the way the commissioner applied the regulation was "so broad in scope and so rigid in terms as to be arbitrary and unreasonable." ${ }^{\prime} 4$ The ruling turned primarily on a state civil rights law guaranteeing all citizens the right to seek redress of employment grievances, which the court interpreted as prohibiting the commissioner from retaliating against firefighters for complaining to the media about the way their grievances were handled. ${ }^{65}$

When Pickering came along in 1968, it did nothing to upset the presumption that government agencies cannot categorically prevent employees from speaking out on matters of public concern. Applying the Pickering balancing test, lower courts routinely struck down overly broad policies that unduly interfered with public employees' communications with journalists and the public.

For example, a federal district court decided in 1981 that the Chicago Fire Department's policy prohibiting unapproved interviews with the media ("whether on or off duty") about matters "pertaining to [Fire] Department activities" was unconstitutionally vague and overbroad. ${ }^{66} \mathrm{~A}$

\footnotetext{
of a Public Employee in Buazard v. Meridith, 33 CREIGHTON L. REv. 417, 463 (2000) (asserting that, as a result of the Eighth Circuit's expansive application of Connick, "the risk exists that public employees will be unable to turn to the judicial system for protection when faced with a decision to either participate in improper activity or decline to at the risk of losing their jobs").

61. 268 U.S. 652, 666 (1925).

62. Kane v. Walsh, 66 N.E.2d 53, 56-57 (N.Y. 1946).

63. Id. at 55 .

64. Id. at 56 .

65. Id. at $56-57$.

66. Grady v. Blair, 529 F. Supp. 370, 371-72 (N.D. Ill. 1981).
} 
state-court judge in New York, applying Pickering, found that a municipal policy that forbade firefighters from discussing "for publication, matters concerning the department" without supervisory approval was invalid because it could "stifl[e] what may be just criticism by a public servant concerning a matter of public concern." ${ }^{67}$ By contrast, an Illinois sheriff's narrower policy, which forbade officers from speaking without approval only "when acting as departmental representatives," survived a facial overbreadth challenge under the Seventh Circuit's application of Pickering. ${ }^{68}$

One discordant note for employee rights came in the Fifth Circuit's split decision in Moore v. City of Kilgore. ${ }^{69}$ There, the court ruled 3-0 in favor of a demoted firefighter in his "as-applied" challenge to punitive action taken in response to statements in a television interview about the fire department's depleted manpower after recent layoffs. ${ }^{70}$ A two-judge majority found that firefighter Gary Moore lacked standing for his facial challenge to the fire department's requirement of prior approval before speaking to the media, but, in dicta, expressed serious doubt that the rule could be challenged on overbreadth grounds. ${ }^{71}$ The majority focused on the fact that Moore was merely punished after speaking, and not prevented from speaking. ${ }^{72}$ But in dissent, Judge Irving L. Goldberg characterized the department's policy as a "classic" unlawful prior restraint:

[T]he Kilgore Rule directs Moore, or any other Fire Department employee, to seek the Chief's approval before speaking. There are no guidelines for the Chief to apply to decide what to authorize and what not to authorize. In this situation, the Chief has the opportunity to act as a censor of the viewpoints of the fire department's employees. If the speaker must seek permission or review before speaking, then the system is a prior restraint. ${ }^{73}$

67. Steenrod v. Bd. of Eng'rs of Fire Dep't, 87 Misc. 2d 977, 978-79 (N.Y. Sup. Ct. 1976); see also Hall v. Mayor of Pennsauken, 422 A.2d 797, 799-800 (N.J. Super. Ct. App. Div. 1980) (holding that law enforcement agency's policy forbidding criticism of superior officers was invalid, because it prohibited even speech related to matters of public concern that did not adversely affect the functioning of the department).

68. Zook v. Brown, 748 F.2d 1161, 1167 (7th Cir. 1984). The court declined to assess the facial validity of a second policy, restricting officers from unapproved speech in advertisements or testimonials, remanding that issue for further development. Id. at 1168.

69. 877 F.2d 364 (5th Cir. 1989).

70. Id. at $367-68,376-77$.

71. Id. at 377 .

72. Id. at 385 (Goldberg, J., dissenting).

73. Id. at 386 (Goldberg, J., dissenting). Judge Goldberg relied principally on the Supreme Court's Lovell v. City of Griffin, 303 U.S. 444, 447, 453 (1938), in which the Court vacated the conviction of a Georgia woman penalized for violating a city ordinance requiring the city manager's 
Judge Goldberg's opinion presciently anticipated how the Supreme Court would soon resolve the issue.

\section{THE NTEU STANDARD AND PRIOR RESTRAINTS}

\section{A. The NTEU Decision: Unmuting Federal Employees}

The Supreme Court did not deal directly with a blanket restriction on government employee speech until United States v. National Treasury Employees Union (NTEU) ${ }^{74}$ In that 1995 ruling, the Court struck down an ethics statute prohibiting federal workers from accepting payment for speeches or articles. ${ }^{75}$

The statute originated with a federal ethics commission's study raising alarm over the risk that members of Congress could be influenced by speaking fees from special-interest groups with a stake in federal legislation. ${ }^{76}$ But the Court found that the ban was not narrowly tailored to advance the stated justification of curbing influence-buying, noting that even low-level employees with minimal policy-making authority would be affected: "Deferring to the Government's speculation about the pernicious effects of thousands of articles and speeches yet to be written or delivered would encroach unacceptably on the First Amendment's protections." $" 77$

The NTEU Court found the prohibition especially offensive to the First Amendment because it constituted a prior restraint against speech, as opposed to an after-the-fact penalty imposed on an individual speaker. ${ }^{78}$ Because the statute chilled many thousands of speakers from even attempting to speak, the Government's burden of justification was greater than in justifying "an isolated disciplinary action."79 That the restriction was merely on receiving payment rather than on speaking at all, the justices concluded, was immaterial, as its purpose and effect was to inhibit employees from speaking about matters within their expertise. ${ }^{80}$

\footnotetext{
written approval for distributing handbills. Id. at 387 (Goldberg, J., dissenting).

74. 513 U.S. 454, 474 (1995).

75. Id. at 457 .

76. Id. at $457-58$.

77. Id. at 475 n. $21,476-77$.

78. Id. at 468 .

79. Id.

80. See id. at 468-69 ("Although [the statute] neither prohibits any speech nor discriminates among speakers based on the content or viewpoint of their messages, its prohibition on compensation unquestionably imposes a significant burden on expressive activity... [C]ompensation provides a significant incentive toward more expression. By denying respondents that incentive, the honoraria ban induces [employees] to curtail their expression if they wish to continue working for the
} 
Referencing the Pickering standard, the Court observed that the speech curtailed by the statute addressed matters of public concern and was delivered in the plaintiff employees' citizen capacity: "The speeches and articles for which they received compensation in the past were addressed to a public audience, were made outside the workplace, and involved content largely unrelated to their government employment." 81

The government argued that the ban was needed to uphold the integrity of public service and to promote the efficient operation of government. ${ }^{82}$ The Court found this argument unpersuasive. ${ }^{83}$ Absent a nexus that connected the employees' speech directly to their work responsibilities, there was "no corrupt bargain or even appearance of impropriety." 84

Under the NTEU test, where the government singles out expressive activity for regulation to address anticipated harms, the government must "demonstrate that the recited harms are real, not merely conjectural, and that the regulation will in fact alleviate these harms in a direct and material way." 85

\section{B. NTEU in Action}

Following NTEU, lower courts regularly struck down gag orders imposed by state and local agencies that purported to require employer approval of all contact with the media. Indeed, no "prior restraint" on public employee speech, even outside the context of media interviews, appears to survive constitutional challenge once the strong medicine of $N T E U$ is found to apply.

In an oft-cited case applying NTEU, Harman v. City of New York, the Second Circuit found that two New York City agencies overreached in prohibiting employees from communicating with the media about agency policies or activities without prior agency approval. ${ }^{86}$ The challenge focused on a policy disseminated by the city's Administration of Children's Services, which stated:

All contacts with the media regarding any policies or activities of the Agency-whether such contacts are initiated by media representatives

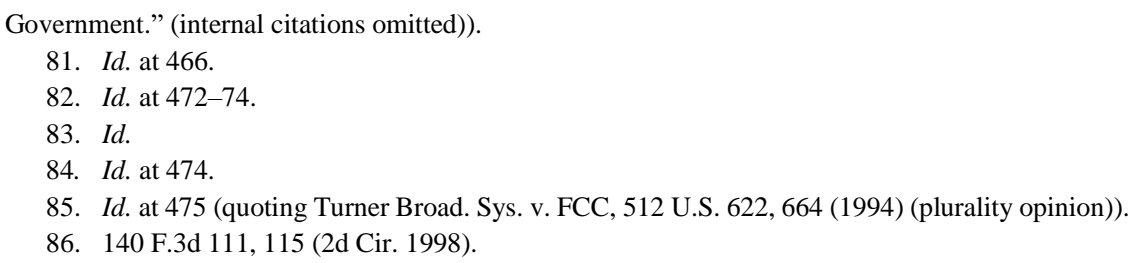


or by an Agency employee - must be referred to the ACS Media Relations Office before any information is conveyed by an employee or before any commitments are made by an employee to convey information. The ACS Media Relations Office will determine the appropriate manner in which to handle media contacts regarding Agency policies or activities, including the appropriate person or persons to make such contacts, consistent with the efficient and effective operation of the Agency and the achievement of its objectives. ${ }^{87}$

The Second Circuit noted that the ban prohibited speech that was of concern to the public. ${ }^{88}$ Therefore, the city bore "the burden of demonstrating that the challenged policies are necessary to the efficient operation of the agencies." ${ }^{89}$ The burden is particularly high where the blanket ban was prospective, as opposed to retrospective, or in response to an individual who had already spoken with the media. ${ }^{90}$ To justify this ban, "the Government must show that the interests of both potential audiences and a vast group of present and future employees in a broad range of present and future expression are outweighed by that expression's 'necessary impact on the actual operation' of the Government." ${ }^{\text {"1 }}$ The court observed that New York City's ban was even broader than the federal ban that was struck down in NTEU, which burdened employee speech only indirectly by removing the speaker's financial incentive. ${ }^{92}$

Similarly, the Third Circuit (in an opinion written by future Justice Samuel Alito) applied NTEU to invalidate a Pittsburgh Police Bureau

87. Id. at 116 .

88. Id. at $117-18$.

89. Id. at 118 .

90. Id.

91. Id. (citing United States v. Nat'1 Treasury Emps. Union, 513 U.S. 454, 468 (1995)).

92. Id. at 119. Multiple district courts have followed Harman in invalidating policies that broadly restrict public employees from discussing their work with the media. See, e.g., Davis v. Phenix City, No. 3:06cv544-WHA, 2008 WL 401349, at*9-13 (M.D. Ala. Feb. 12, 2008) (finding that Alabama fire department's policies against discussing work-related matters with the media and the city council could be viewed as prior restraints under Harman and NTEU and were facially overbroad because they did not make any exception for matters of public concern such as complaints about inadequate staffing levels); Price v. Saugerties Cent. Sch. Dist., No. 105CV0465LEKDRH, 2006 WL 314458, at *1, *6 (N.D.N.Y. Feb. 9, 2006) (striking down a gag order that forbade school employees from lodging complaints outside their chain of command, which was used to discipline a teacher who reported concerns about inadequate employee training and support to members of the local school board and also contacted police about a dangerous prank that her supervisors failed to investigate seriously). By contrast, a district court in Connecticut distinguished Harman and NTEU in rejecting a facial challenge to a narrower set of restrictions applying only to "formal" news releases or the release of "confidential" information. Shelton Police Union v. Voccola, 125 F. Supp. 2d 604, 623-25 (D. Conn. 2001). The court in the Shelton Police case ultimately ruled in the employee's favor in an as-applied challenge, finding that the employer failed to satisfy the Pickering standard in disciplining a police officer who publicly criticized the police chief for making racially offensive remarks. Id. at 630 . 
policy restricting officers' freedom to offer expert witness testimony. ${ }^{93}$ The policy at issue provided that "written authorization from the Chief of Police must be given before any member [of the force] may testify as an expert witness." 94 The trial court analyzed the statute as a prior restraint under the NTEU standard and found it unconstitutionally overbroad, and the Third Circuit agreed. ${ }^{95}$ Citing Harman, the court applied the more demanding version of the Pickering balancing-of-interests test that applies to a policy of prior restraint, and found the policy insufficiently welltailored to accomplish the proffered objective of avoiding public confusion about the police department's official position. ${ }^{96}$ The speech at issue, then-Judge Alito wrote, plainly touched on matters of public concern, and the policy did not limit itself to the disclosure of only confidential information - which, in any event, preexisting department policy already prohibited. ${ }^{97}$

The Seventh Circuit applied NTEU to assess the constitutionality of a Milwaukee Police Department policy prohibiting employees from discussing the substance of formal grievance filings with any outsiders, even their own lawyers or union representatives. ${ }^{98}$ Opening with an immortally dismissive line- "This is one of those cases in which litigation seems to have replaced common sense"-Judge Ilana Rovner's opinion relied on Harman in concluding that the department's policy required a rigorous NTEU analysis because of its impact on all would-be speakers: "With a prior restraint, the impact is more widespread than any single supervisory decision would be, and the action chills potential speech instead of merely punishing actual speech already communicated." 99

In a factually novel case extending beyond the traditional employment setting, the Seventh Circuit subsequently relied on NTEU in striking down a University of Illinois policy forbidding anyone "associated with" the university from communicating with a prospective athletic recruit without the athletic director's authorization. ${ }^{100}$ The case was brought by students and faculty members who sought to enlist star athletic prospects in their campaign to change the university's cartoonishly stereotypical Native

93. Swartzwelder v. McNeilly, 297 F.3d 228, 231, 237, 242 (3d Cir. 2002).

94. Id. at 232 .

95. Id. at $233,241-42$.

96. Id. at $235-36,240$.

97. Id. at $238-39$.

98. Milwaukee Police Ass'n v. Jones, 192 F.3d 742, 744-45, 749-50 (7th Cir. 1999).

99. Id. at 744, 750 (citing United States v. Nat'l Treasury Emps. Union, 513 U.S. 454, 468 (1995)).

100. Crue v. Aiken, 370 F.3d 668, 674-75, 680 (7th Cir. 2004). 
American mascot. ${ }^{101}$ While the policy applied to students and alumni as well as employees, the appeals court found the NTEU framework applicable because of the sweeping breadth of the prohibition, and invalidated the rule as overbroad. ${ }^{102}$

Over and over, post-NTEU cases brought by police officers or firefighters ended with the same result: A directive that employees refrain from discussing their work with the media, or obtain supervisory approval before doing so, violates the First Amendment. ${ }^{103}$ Among the policies struck down in the aftermath of NTEU include:

- A fire chief's order telling employees that "only the Chief of Department has the authority to discuss for publication, matters concerning the Department," with violation of the order punishable by disciplinary sanction. ${ }^{104}$

- A regulation forbidding officers of a state police agency from disclosing "any information not generally available to members of the public which such member receives or acquires in the course of and by reason of official duty" without supervisory approval, and requiring employees to treat "any matters or information" pertaining to the agency as confidential. ${ }^{105}$

- A police department's rule providing that only the police chief or the chief's designee could release information to the media "relative to questions of enforcement policy; disciplinary action against a member of the department; organizational changes; policy statements; annual reports or crime statistics;

101. Id. at $674-75$.

102. Id. at $678-80$.

103. Policies that restrict only critical or unfavorable speech about the employer are similarly infirm, whether viewed as prior restraints under the NTEU standard or as viewpoint-discriminatory under a more traditional First Amendment analysis. See, e.g., Westbrook v. Teton Cty. Sch. Dist. No. 1, 918 F. Supp. 1475, 1481, 1489, 1498 (D. Wyo. 1996) (finding school district's policy forbidding criticism of co-workers or supervisors, including members of the school board, outside of limited settings to be unconstitutionally overbroad). Interestingly, the court in Westbrook, though its ruling followed NTEU by just thirteen months, neither mentioned the Supreme Court's ruling nor applied its prior-restraint analysis, yet reached the same result anyway. $I d$.

104. Providence Firefighters Local 799 v. City of Providence, 26 F. Supp. 2d 350, 352, 357 (D.R.I. 1998). The order augmented an existing regulation requiring the fire chief's pre-approval before making any comments for publication, which the court likewise found unconstitutionally overbroad. Id. at $352,357$.

105. Davis v. N.J. Dep't of Law \& Pub. Safety, 742 A.2d 619, 622-23, 636 (N.J. Super. Ct. Law Div. 1999). The policy was challenged in the context of a race discrimination complaint by black officers, who were inhibited from granting requests for interviews from the news media about their discrimination case because of the regulation. Id. at 622 . 
answers to criticism against the department; "mug' shots."106

- A directive requiring "express authorization" before any member of a police department could speak to the news media and forbidding any officer from making "any public statement regarding a private matter of this department."107

- A highway patrol agency's policy forbidding troopers from making "official comments relative to department policy" to members of the press or public without supervisory approval. ${ }^{108}$

- A Massachusetts fire department regulation prohibiting employees from making "statements for publication concerning the plans, policies, or affairs of the administration of the fire department unless authorized to do so by the commissioner and chief." 109

In an especially extreme case where firefighters were gagged by a municipal ordinance carrying criminal penalties of up to ninety days in jail, a Michigan district court applied NTEU to throw out the ordinance as unconstitutional. ${ }^{110}$ The court found the ordinance fatally overbroad because it required employees to refer all requests for comment to the fire chief "regarding the policies, procedures, practices and/or operation of the fire department." 111 Although the agency insisted that the policy was intended only to restrict "official" statements made on behalf of the fire department, the court found no such limiting application could be inferred from the plain wording of the ordinance, which would chill all employee speech. ${ }^{112}$ The court also rejected the fire department's insistence that the ordinance should be viewed under the more employer-friendly standard of Pickering:

Pickering, however, is only applicable where the employee has been punished after speaking in an ad hoc disciplinary action. When, in contrast, the restriction on speech takes the form of a pre-speech threat of punishment that deters employees from engaging in the speech, the

\footnotetext{
106. Wagner v. City of Holyoke, 100 F. Supp. 2d 78, 89-90 (D. Mass. 2000).

107. Kessler v. City of Providence, 167 F. Supp. 2d 482, 483, 490 (D.R.I. 2001).

108. Lauretano v. Spada, 339 F. Supp. 2d 391, 414-15, 420 (D. Conn. 2004).

109. Parow v. Kinnon, 300 F. Supp. 2d 256, 260, 266 (D. Mass. 2004).

110. Int'l Ass'n of Firefighters Local 3233 v. Frenchtown, 246 F. Supp. 2d 734, 736, $739-44$ (E.D. Mich. 2003).

111. Id. at $736,743-44$

112. Id. at 738-39.
} 
proper test is the more stringent one elucidated in NTEU. ${ }^{113}$

The court went on to explain that NTEU is the more demanding standard because it requires the government to "show that the speech being restricted necessarily would have impacted the actual operation of the government," which the fire department could not do in defending the ordinance. ${ }^{114}$

Affirming that employers retain some authority over public employees' speech, the Second Circuit rejected an NTEU-based challenge to a New York Police Department policy requiring only the officers to provide advance notice before giving a speech and a written summary of their remarks the following business day. ${ }^{115}$ Distinguishing the more onerous pre-approval policy found unlawful in Harman, the court was unpersuaded that merely requiring notification would be so intimidating as to deter a reasonable officer from speaking freely: "In the absence of the approval requirement, there is no opportunity for the City to suppress or delay speech expressing dissenting views." ${ }^{116}$ Notably, the police department's successful defense of the notification policy relied in part on assuring the court that the policy governed only "speeches" and not remarks made to the news media: "The release to the media of information concerning official business of the NYPD is governed by a separate provision ... which encourages officers 'to facilitate the accurate, timely and proper dissemination of information' to the public."117 Thus, the Second Circuit's resolution of the Latino Officers case is a narrow one that says nothing about whether a prior approval policy before speaking to the news media would be constitutional. ${ }^{18}$

\section{Id. at 740 .}

114. Id. at $740-41$.

115. Latino Officers Ass'n v. Safir, 170 F.3d 167, 168, 172-73 (2d Cir. 1999). The "notice and reporting" policy was a significant concession by police authorities from the more rigid prior approval policy that the Latino officers initially challenged, resulting in a NTEU-based ruling enjoining enforcement of the broader policy. Latino Officers Ass'n v. Safir, No. 97 Civ. 3143 (SHS), 1997 WL 426099 , at $* 2, * 13$ (S.D.N.Y. July 30, 1997). Because the NYPD rescinded the preapproval aspect of the policy by virtue of a consent decree with the Latino officers, the Second Circuit considered only the remaining, less restrictive provisions. Latino Officers Ass'n, 170 F.3d at 173.

116. Latino Officers Ass' $n, 170$ F.3d at 172.

117. Id. at 170 .

118. See Davis v. N.J. Dep’t of Law \& Pub. Safety, 742 A.2d 619, 630 (N.J. Super. Ct. Law Div. 1999) (distinguishing Latino Officers in the case of a policy that required prior approval as opposed to merely prior notice and reading the Latino Officers case to imply that a policy actually allowing supervisors to delay or suppress speech would be "constitutionally troublesome"). In summarily dismissing an employee's facial challenge to a mandatory prior notification policy before employees of a city housing department could speak to the media, a district court recognized the distinction as decisive: "[T]he media policy does not seek to enjoin speech or require advance approval. Rather, it simply requires notification before an employee speaks to the press .... Therefore, as written it is not 


\section{GARCETTI CHANGES THE GAME (OR DOES IT?)}

\section{A. Garcetti and Its Impact on Speech "Pursuant to" Official Duties}

In Garcetti v. Ceballos,${ }^{119}$ the Supreme Court made it more difficult for a public employee disciplined for the content of speech to establish a First Amendment claim. There, the Court found that speech by a government employee, even when addressing matters of public concern, is not protected by the First Amendment if it is made "pursuant to" the employee's official duties. ${ }^{120}$

In Garcetti, prosecutor Richard Ceballos was punished for speech that departed from the position of his employer, the Los Angeles County District Attorney's Office, on a pending criminal case. ${ }^{121}$ Specifically, Ceballos alleged he was demoted and suffered other retaliatory acts because he wrote a memo that cast doubt on the validity of evidence used to support a search warrant and arrest, and then testified on behalf of the arrestee when his case went to trial. ${ }^{122}$ Ceballos argued that both the memo and the testimony were constitutionally protected speech, but in a 5-4 opinion written by Justice Anthony Kennedy, the Supreme Court disagreed. ${ }^{123}$

The Court recognized that the fact that "Ceballos expressed his views inside his office, rather than publicly, is not dispositive," as speech may be constitutionally protected even when directed internally up the chain of command. ${ }^{124}$ But the Court concluded that this particular speech was unprotected as "speech that owes its existence to a public employee's professional responsibilities." 125 The Court thus carved out a categorically unprotected subset of employee speech: "We hold that when public employees make statements pursuant to their official duties, the employees are not speaking as citizens for First Amendment purposes, and the Constitution does not insulate their communications from employer discipline." 126

The majority reasoned that a government employer's interest is at its

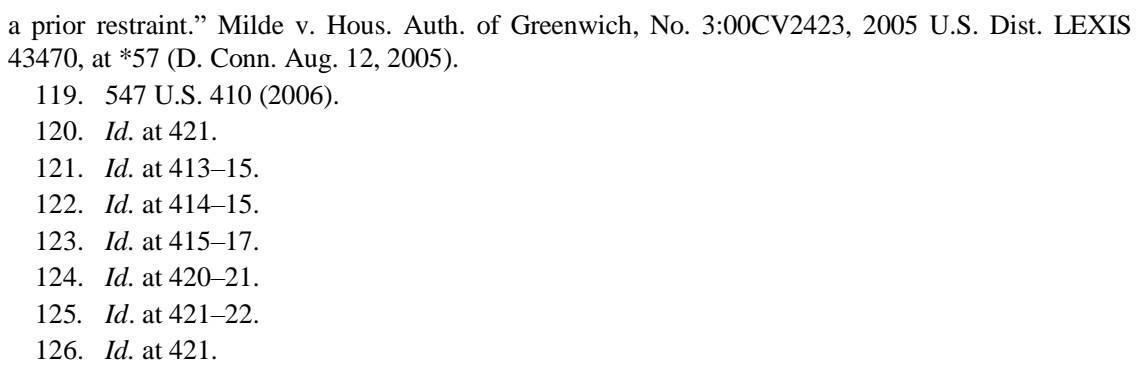


highest, and the employee's interest in self-expression is at its lowest, when the speech is itself a job responsibility, as with Ceballos's memo and testimony, both of which would be routine parts of a deputy district attorney's responsibilities. ${ }^{127}$ Because of the government's overriding interests, including consistency and accuracy in promulgating the agency's message, the Court found that statements made pursuant to official duties cease to be protected by the First Amendment at all, and the employer may freely regulate those statements without needing any justification. ${ }^{128}$

The pronouncement that some employee speech is entirely beyond the reach of the Constitution fueled fears of an "open season" on whistleblowers who, like Ceballos, exercise independent professional judgment in the face of agency action they perceive as wrongful. One commentator fretted that the ruling "has now made it nearly impossible for conscientious public servants to speak out in the best interests of the public without jeopardizing their careers."129 Another stated: "[T]he Garcetti rule works as a bludgeon against public employee speech when a scalpel offers a more appropriate tool for parsing government's legitimate expressive interests in its workers' on-duty speech."130 Other analysts, focusing on the setting in which Ceballos's speech occurred-in a memo assigned by a supervisor - theorized that the case might not have much effect at all on claims brought by people who "blow the whistle" externally to a public audience. ${ }^{131}$

127. Id. at 422 .

128. See id. at 422-23 ("Employers have heightened interests in controlling speech made by an employee in his or her professional capacity. Official communications have official consequences, creating a need for substantive consistency and clarity. Supervisors must ensure that their employees' official communications are accurate, demonstrate sound judgment, and promote the employer's mission.").

129. Paul M. Secunda, Garcetti's Impact on the First Amendment Speech Rights of Federal Employees, 7 FIRST AMEND. L. REV. 117, 117 (2008); see also id. at 127 (observing that, because the takeaway from Garcetti is that speakers are better-protected if they immediately go to the public with their concerns rather than proceed through in-house dispute-resolution channels, "this state of affairs leads to a tremendous waste of judicial resources on unnecessary litigation that might have been resolved internally").

130. Helen Norton, Constraining Public Employee Speech: Government's Control of Its Workers' Speech to Protect Its Own Expression, 59 DuKE L.J. 1, 30 (2009) (proposing, as an alternative approach, that speech pursuant to governmental duties should lose First Amendment protection only when the employee is hired for the purposes of expressing the government's message and is doing so in a way that would be transparent to the audience, as in the case of a press secretary hired by a school board).

131. See, e.g., Robert J. Tepper \& Craig G. White, Speak No Evil: Academic Freedom and the Application of Garcetti v. Ceballos to Public University Faculty, 59 CATH. U. L. REv. 125, 147-48 (2009) (suggesting that the Garcetti ruling "may not effectuate a large change in this area" because its holding "may not apply when the employee speaks or complains outside the chain of command"). 
Notably, the Garcetti majority, harkening back to Pickering's facts, explicitly mentioned "writing a letter to a local newspaper" as the type of speech that would likely be unaffected by the Court's newly recognized standard. ${ }^{132}$ The majority appeared to draw a distinction between speech that could occur uniquely within the government workplace, which would be unprotected, versus speech that could come from a citizen outsider, which would remain protected. ${ }^{133}$

Since Garcetti, the question of when speech qualifies as "pursuant to official duties" has been litigated extensively, with frustratingly inconsistent results. ${ }^{134}$ Some courts have faithfully applied Garcetti in accordance with its plain language and found that speech to journalists or to the general public does not lose First Amendment protection unless the speech is itself a work assignment. Thus, when a New Hampshire tax assessor lost his job over comments in a newspaper interview in which he questioned the fairness of the tax system, the state Supreme Court confined the reach of Garcetti to the scope of the assessor's duties enumerated in his official job description, which "does not indicate that the plaintiff is required to communicate with the public on any matter other than the office's procedures and techniques." 135 The comments thus fell beyond the scope of Garcetti and could be protected. ${ }^{136}$

But at times, courts have aggressively construed Garcetti to reach speech that relates to the subject matter of the employee's work, or that would not exist but-for the speaker's employment, even when the speech was far from being a routine duty to which the employee would be assigned. ${ }^{137}$ For example, the Seventh Circuit found that a Milwaukee

132. Garcetti, 547 U.S. at 423.

133. See id. ("Employees who make public statements outside the course of performing their official duties retain some possibility of First Amendment protection because that is the kind of activity engaged in by citizens who do not work for the government."). The Tenth Circuit applied this distinction in rejecting the First Amendment claim of a lab technician at a state detention center who internally challenged the reliability of the center's drug tests, stating that the employee "was not communicating with newspapers or her legislators or performing some similar activity afforded citizens." Green v. Bd. of Cty. Comm'rs, 472 F.3d 794, 796-97, 800 (10th Cir. 2007).

134. For criticism of the uncertain state of employee speech rights left in Garcetti's wake, see Paul M. Secunda, Whither the Pickering Rights of Federal Employees?, 79 U. CoLO. L. REV. 1101, 1133 (2008) (commenting that "Garcetti is a prime example of poor judicial reasoning and opinion writing" that has invited misapplication to the detriment of employee speakers); Charles W. "Rocky" Rhodes, Public Employee Speech Rights Fall Prey to an Emerging Doctrinal Formalism, 15 WM. \& MARY BILL RTS. J. 1173, 1193-94 (2007) ("Rather than the relatively stable balancing process that had become familiar in these cases, the lower courts are now confronted with an inexact classification prerequisite that is already generating unpredictable results.").

135. Snelling v. City of Claremont, 931 A.2d 1272, 1277-78, 1281 (N.H. 2007).

136. Id. at 1281 .

137. See Heidi Kitrosser, The Special Value of Public Employee Speech, 2015 SUP. CT. REV. 301, 311 (2015) ("Some lower courts, relying on Garcetti's statement that speech is unprotected when it 
police officer who reported to the local prosecutor's office that his boss had been helping her fugitive brother evade arrest on an outstanding drug warrant did not have a First Amendment claim for his retaliatory reassignment to undesirable duties. ${ }^{138}$ The court held that, because police department policy required officers to report all crimes they became aware of, and because the conversation between the officer and the prosecutor occurred during an official-duty meeting to go over an arrest report, the speech was made in the officer's official capacity and entitled to no First Amendment protection. ${ }^{139}$

Whether the employee was punished for speech internal to the agency or speech made to the public has proven to be an influential and at times decisive consideration. When speech is simply reported to co-workers or supervisors through a routine workplace chain-of-command, it is more likely to be regarded as on-duty Garcetti speech, and when speech is conveyed to a larger public audience, it is more likely to be protected. ${ }^{140}$ A number of post-Garcetti cases have explicitly made this distinction, protecting employees because they directed their complaints externally to the news media. ${ }^{141}$ As the Fifth Circuit summarized it, in the case of a University of Texas employee who complained both internally and externally about what she perceived to be management's indifference to employees' use of computers to view pornography:

Cases from other circuits are consistent in holding that when a public employee raises complaints or concerns up the chain of command at his workplace about his job duties, that speech is undertaken in the course of performing his job.... If however a public employee takes his job concerns to persons outside the work place in addition to raising them up the chain of command at his workplace, then those external communications are ordinarily not made as an employee, but as a citizen. ${ }^{142}$

\footnotetext{
'owes its existence' to the speaker's public employment, leaned heavily against protecting speech consisting of information learned through such employment.").

138. Morales v. Jones, 494 F.3d 590, 592, 597-98 (7th Cir. 2007).

139. Id. at 597-98.

140. See Christine Elzer, Note, The "Official Duties" Puzzle: Lower Courts' Struggle with First Amendment Protection for Public Employees After Garcetti v. Ceballos, 69 U. PITT. L. REV. 367, 38687 (2007) (recognizing confusion left by Garcetti and observing that "the exact same statement could be protected in one instance and not protected the next, and the only discernable distinction is that some speech is internal and other speech is external").

141. See, e.g., McLaughlin v. City of Nashville, No. 06-4069, 2006 U.S. Dist. LEXIS 78133, at $* 2-3, * 8-9, * 12-13$ (W.D. Ark. Oct. 23, 2006) (finding that McLaughlin, a fired city finance director, had a First Amendment claim for statements made to reporters about report written in the course of her job responsibilities).
}

142. Davis v. McKinney, 518 F.3d 304, 313 (5th Cir. 2008) (internal citations omitted). 
This approach has some logical appeal. Reporting problems to supervisors is far more likely to fall within an employee's routine job duties than speaking with the news media. However, as Justice John Paul Stevens noted in his Garcetti dissent, the resulting incentive system rewards employees who deviate from internal operating procedures and take their complaints public and penalizes those who quietly attempt to resolve problems in-house. ${ }^{143}$

Notwithstanding the widely recognized distinction between "internal" and "external" complaints, employers have at times been permitted to discipline employees who speak to the media, if providing information to the media can be regarded as part of the employee's official duties.

For example, in Foley $v$. Town of Randolph, a municipal fire chief lost his First Amendment challenge to a suspension imposed in response to his comments to the media at the scene of a fatal fire, claiming that the city had deprived the fire department of essential funding and manpower. ${ }^{144}$ Even though the chief's job description said nothing about speaking to the media, the court found the speech unprotected under Garcetti, because the chief was in uniform and on duty at an official press conference convened by the state fire marshal, and he "would naturally be regarded as the public face of the Department when speaking about matters involving the Department." 145 Similarly, in Hurst v. Lee County, the Fifth Circuit held that a corrections officer, who made statements to the media about the arrest of a college football player, "was not speaking as a citizen for First Amendment purposes, and consequently his communications were not constitutionally insulated from employer discipline." ${ }^{146}$ Although the officer insisted that speaking to the media was not part of his official duties, the court was persuaded otherwise, because the sheriff maintained a "media relations policy" that allowed the officer to release certain types of information to journalists about arrestees, and to release even more information after receiving supervisory approval; thus, his job duties in fact contemplated that the officer would speak to the media. ${ }^{147}$

Cases involving speech to journalists are rare. Far more commonly,

143. Garcetti v. Ceballos, 547 U.S. 410, 427 (2006) (Stevens, J., dissenting) (“[I]t seems perverse to fashion a new rule that provides employees with an incentive to voice their concerns publicly before talking frankly to their superiors.").

144. 598 F.3d 1, 2-3, 10 (1st Cir. 2010).

145. Id. at 7 .

146. 764 F.3d 480, 482-83, 485 (5th Cir. 2014) (citation omitted).

147. Id. at 482, 485. Cf. Haverda v. Hays Cty., 723 F.3d 586, 588, 597-98 (5th Cir. 2013) (holding that a corrections officer writing a letter-to-the-editor was speaking as a citizen, rather than as a public employee, where his letter commented on an ongoing campaign for sheriff, attempted to shed light on retaliation within the sheriff's department, and was not part of the officer's job duties or assignments). 
employees are disciplined for whistleblowing speech to regulators or to government overseers. In that scenario, which might be analogized to speaking with journalists, employees' First Amendment claims have fared relatively well. For instance, in Dahlia v. Rodriguez, the Ninth Circuit held that a police officer spoke as a citizen in disclosing his fellow officers' misconduct to the department's Internal Affairs unit. ${ }^{148}$ That the employee made his report to others "outside of his chain of command" was considered a persuasive factor in determining that the speech was not made pursuant to his official duties. ${ }^{149}$ Similarly, in Freitag v. Ayers, the Ninth Circuit held that a correctional officer's reports of a sexually hostile working environment were protected when made to a state senator and to the state Inspector General, but unprotected when contained in a memo written to her direct supervisors. ${ }^{150}$

The post-Garcetti line of cases involving punishment for comments to the media illustrates two realities. First, if speaking to the media is part of an employee's job description, doing that job inconsistently with the employer's wishes will be unprotected speech. Second, it will be easier for an employer to justify individually applied punishment for speech to the media that causes workplace disharmony than to justify a categorical prohibition on unapproved speech.

Garcetti might seem to leave a gaping hole between, on the one hand, speech that is pursuant to official duties, and on the other hand, speech as a citizen addressing a matter of public concern (that is to say, Pickering speech). If given just two ill-fitting choices, courts understandably may be inclined to shoehorn all job-related speech into the unprotected category. But that is unfaithful to the Garcetti majority's own admonition that not all speech about work is work. ${ }^{151}$ Properly understood, Garcetti is about speech that only the government employee would have the ability to engage in by virtue of official authority - that is, writing an internal memo assessing the flaws of a prosecution, not writing a letter-to-theeditor. $^{152}$

Crucially for purposes of pre-enforcement challenges to employer gag policies, Garcetti involved an as-applied challenge to disciplinary action for a particular instance of expression. NTEU, on the other hand, was a facial challenge to a categorical prohibition on certain employee speech. Although Garcetti is widely perceived to have strengthened the

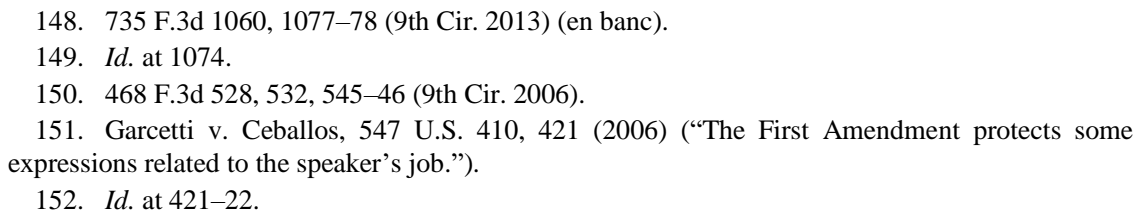


employer's hand in punishing employees who stray "off-message" in their official speech, nothing in the ruling disturbs NTEU nor defensibly can be interpreted as giving sanction to blanket prohibitions on speech about work-related matters.

\section{B. Gag Orders Post-Garcetti}

Since Garcetti, published rulings addressing the constitutionality of workplace gag rules have been infrequent, making it difficult to assess whether the case has influenced judges' analysis. Garcetti played no role in resolving a 2008 facial challenge to an Alabama fire department's policy that forbade officers from discussing work-related matters with the news media and the city council. ${ }^{153}$ In that case, an Alabama district court, without citing Garcetti, relied on NTEU and Harman to conclude that the policy was a facially overbroad prior restraint, because it made no exception for matters of public concern, such as complaints about inadequate staffing. ${ }^{154}$

In a 2013 case influenced by Garcetti, a District of Columbia judge rejected a facial challenge to a police department policy forbidding officers from making unauthorized statements to the public "pertaining to Department policies, procedures, rules, personnel issues and direction."155 The policy was comparable to - and in fact, more encompassing than-a D.C. fire department policy struck down as unconstitutional, pre-Garcetti, by a different District of Columbia judge two decades earlier. ${ }^{156}$ Nevertheless, the police department gag rule survived scrutiny based on what might be called a "Garcetti savings clause," specifying that "participating in an interview to express personal views" was outside the scope of the restrictions. ${ }^{157}$ The employee ultimately prevailed on the asapplied portion of his challenge, because the court found that speaking with the media was not part of his job duties, rejecting the police department's invitation to apply the Garcetti rule broadly to any speech that "owed its existence" to his job or was "related to" his duties. ${ }^{158}$

Regardless of whether Garcetti undermined the vitality of NTEU-a case that the Garcetti majority mentioned only twice, in passing - the reality is that Garcetti fueled a mindset among government managers and

153. Davis v. Phenix City, No. 3:06cv544-WHA, 2008 WL 401349, at*2-3, *10 (M.D. Ala. Feb. $12,2008)$.

154. Id. at *9, *12-13.

155. Hawkins v. District of Columbia, 923 F. Supp. 2d 128, 131, 136 (D.D.C. 2013).

156. Fire Fighters Ass'n v. Barry, 742 F. Supp. 1182, 1194-96 (D.D.C. 1990).

157. Hawkins, 923 F. Supp. $2 d$ at 136.

158. Id. at $139-40$. 
their counsel that the courts would view restrictions on employee speech deferentially. As one media-law professor wrote in assessing the first five years of post-Garcetti caselaw: "The result has been ad hoc, inconsistent and unpredictable outcomes that could easily chill the flow of vital information to the public.... Garcetti may therefore deter even heretofore willing, nonconfidential government sources from cooperating with journalists and providing critical information about the functioning of government." 159 Leaving aside the relatively rare facial challenge to a blanket restraint, employers have in fact enjoyed tremendous deference in the more commonplace case of workers challenging discipline for specific instances of work-related speech. ${ }^{160}$

\section{Lane v. Franks: Putting Garcetti Back in the Bottle}

The Supreme Court's ruling in Lane v. Franks, ${ }^{161}$ involving a whistleblower punished for testifying about corruption in the Alabama community college system, reinforces the narrow view of Garcetti that speech does not lose its protection solely because it is about workplace issues or is based on knowledge gained in the workplace. ${ }^{162}$

In Lane, the former director of a community college's program for underprivileged youth brought a First Amendment retaliation claim against the president of Central Alabama Community College ("CACC"). ${ }^{163}$ As director, Edward Lane audited the program's expenses and discovered that Suzanne Schmitz, an Alabama state legislator on the payroll for the program, had not been reporting for work and terminated her. ${ }^{164}$ Her firing drew the attention of federal authorities, who opened an investigation leading to Schmitz's indictment on charges of mail fraud and theft. ${ }^{165}$ Lane testified, under subpoena, before a federal grand jury about why he removed Schmitz. ${ }^{166}$ Shortly afterward, President Steve Franks

159. Robert E. Drechsel, The Declining First Amendment Rights of Government News Sources: How Garcetti v. Ceballos Threatens the Flow of Newsworthy Information, 16 COMM. L. \& POL'Y 129, 132 (2011) (emphasis added).

160. See Norton, supra note 130, at 4 (criticizing courts' "unblinking deference" to employers' assertions that employee speech was job-related for purposes of Garcetti, even when the speech involves "prosecutors disciplined for criticizing police work, government workers fired after reporting public officials' financial or ethical improprieties, and department heads terminated for criticizing administration priorities").

161. 573 U.S. 228 (2014).

162. Id. at $232-33,238-39$.

163. Id. at 231-34.

164. Id. at 232 .

165. Id.

166. Id. at $232-33$. 
fired Lane as part of what he termed a financial austerity cutback, although evidence emerged casting doubt on the veracity of that explanation. ${ }^{167}$

Lane challenged his removal as a violation of his First Amendment rights, but the lower courts dispensed with the case on Garcetti grounds. ${ }^{168}$ In a short unpublished opinion, the Eleventh Circuit U.S. Court of Appeals observed that Lane's testimony "touched only on acts he performed as part of his official duties," and concluded that "because formal job descriptions do not control, that Lane's official duties did not distinctly require him to testify at criminal trials falls short of triggering First Amendment protection." 169

The Supreme Court reversed. ${ }^{170}$ The justices held that Lane's grand jury testimony fell outside the scope of his ordinary job duties and thus was entitled to First Amendment protection: "Truthful testimony under oath by a public employee outside the scope of his ordinary job duties is speech as a citizen for First Amendment purposes. That is so even when the testimony relates to his public employment or concerns information learned during that employment."171 The Court explained:

Sworn testimony in judicial proceedings is a quintessential example of speech as a citizen for a simple reason: Anyone who testifies in court bears an obligation, to the court and society at large, to tell the truth . . . . That independent obligation renders sworn testimony speech as a citizen and sets it apart from speech made purely in the capacity of an employee. ${ }^{172}$

The Court distinguished its holding from Garcetti, noting that "Garcetti said nothing about speech that simply relates to public employment or concerns information learned in the course of public employment." 173 The majority framed the "critical" question under Garcetti as "whether the speech at issue is itself ordinarily within the scope of an employee's duties, not whether it merely concerns those duties."174 In its most crucial observation, the Lane Court clarified the inartful and misunderstood Garcetti phrase ("speech that owes its existence to a public

\footnotetext{
167. Id. at $233-34$.

168. Id. at 234-35.

169. Lane v. Cent. Ala. Cmty. Coll., 523 Fed. App'x 709, 712 (11th Cir. 2013) (citations omitted), aff'd in part, rev'd in part and remanded sub nom. Lane v. Franks, 573 U.S. 228 (2014).

170. Lane, 573 U.S. at $246-47$.

171. Id. at 238 .

172. Id. at $238-39$.

173. Id. at 239 .

174. Id. at 240 .
} 
employee's professional responsibilities") ${ }^{175}$ by stating that "the mere fact that a citizen's speech concerns information acquired by virtue of his public employment does not transform that speech into employee-rather than citizen-speech."176

With Garcetti out of the picture, the Court applied the Pickering balancing-of-interests test, first noting that Lane's testimony was speech on a matter of public concern - corruption in a publicly funded program and misuse of state funds. ${ }^{177}$ Then the justices looked for the government's legitimate interests in suppressing Lane's speech - and found nothing: "the employer's side of the Pickering scale is entirely empty." 178 Hence, Lane's removal violated his constitutional rights. ${ }^{179}$

The Lane analysis puts a helpfully clarifying gloss on Garcetti reemphasizing the literalness of its core holding: that speech loses its First Amendment protection only if the speech is itself a work assignment, such as Ceballos's act of writing a legal memo to submit to his supervisor, Garcetti. ${ }^{180}$ This makes a potentially decisive difference for employees forbidden by their superiors from speaking to the media or penalized afterthe-fact for doing so, because giving interviews rarely will be a part of (to use the Lane phrase) an employee's "ordinary job responsibilities." 181

\section{Gag Orders Post-Lane}

To date, the only appellate court to entertain a facial challenge to a blanket gag policy on public employees since Lane concluded that the policy was unconstitutionally overbroad, in part relying on Lane.

In that case, Moonin v. Tice, a Nevada state patrol officer challenged a directive forbidding members of his agency's dog-handling unit from

\footnotetext{
175. Garcetti v. Ceballos, 547 U.S. 410, 421-22 (2006).

176. Lane, 573 U.S. at 240 .

177. Id. at 242 .

178. Id.

179. Id. In a brief concurrence, Justices Thomas, Scalia, and Alito wrote to emphasize that, although Lane's testimony was not pursuant to official duties, it cannot categorically be said that government employees always testify in their role as private citizens, since some testimony (for instance, by police) is part of an assigned job duty. Id. at 247 (Thomas, J., concurring).

180. See John E. Rumel, Public Employee Speech: Answering the Unanswered and Related Questions in Lane v. Franks, 34 HOFSTRA LAB. \& EMP. L.J. 243, 246 (2017) ("[T] he Supreme Court's use of the term 'ordinary job responsibilities' in Lane will likely narrow the scope of public employee speech excepted from First Amendment protection."). As Professor Heidi Kitrosser observes, however, some courts continue being influenced by the persistent Garcetti line, though arguably dicta, that speech is unprotected if it "owes its existence" to public employment. See Kitrosser, supra note 137, at 316-17 (stating that post-Lane opinions from the Fifth, Ninth and Eleventh Circuits can be read as adhering to the broader, pre-Lane understanding of Garcetti).
}

181. Lane, 573 U.S. at 238. 
speaking with anyone outside of law enforcement "for the purpose of discussing the Nevada Highway Patrol K9 program or interdiction program, or direct and indirect logistics therein," under threat of discipline for insubordination. ${ }^{182}$ The policy was an attempt to dampen criticism of the canine program that some perceived as wasteful and ineffective. ${ }^{183}$

A district court found the policy so clearly unconstitutional as to defeat the individual supervisory defendants' claim of qualified immunity. ${ }^{184}$ At the Ninth Circuit, the highway patrol's counsel argued that the policy restricted only speech governed by Garcetti - that is, speech in which the employee had no individual First Amendment interest-because it was meant to restrict only speech in an official capacity. ${ }^{185}$ The Ninth Circuit was unpersuaded. ${ }^{186}$

Citing Lane's admonition that the expert perspectives of government insiders are of special value to the public, the Ninth Circuit observed that "we may not assume that the troopers speak as employees rather than citizens on every occasion in which they discuss information learned or opinions developed while on the job." 187

The court examined the highway patrol's policy by applying the Pickering balancing-of-interests test, with the qualifier that prior restraints bear an especially heavy burden of justification. ${ }^{188}$ While it was not entirely clear what level of scrutiny the court applied, the opinion found the directive wanting because it lacked a "close and rational relationship to the department's legitimate interests." 189 The judges found the agency's primary stated justification for the ban- "ensuring effective operation of the agency without disruption"- - to be speculative:

Although it could be true that police departments would operate more efficiently absent inquiry into their practices by the public and the legislature, efficiency grounded in the avoidance of accountability is not, in a democracy, a supervening value. Avoiding accountability by reason of persuasive speech to other governmental officials and the public is not an interest that can justify curtailing officers' speech as citizens on

182. 868 F.3d $853,858-59$ (9th Cir. 2017).

183. Id. at 859,864 .

184. Moonin v. Nevada ex rel. Dep't of Pub. Safety Highway Patrol, 960 F. Supp. 2d 1130, 1141 (D. Nev. 2013), aff'd sub nom. Moonin v. Tice, 868 F.3d 853 (9th Cir. 2017).

185. Opening Brief of Defendant-Appellant, Moonin v. Tice, 868 F.3d 853 (9th Cir. 2017) (No. 15-16571), 2016 WL 2342549, at *11-12.

186. Moonin, 868 F.3d at $862-64$.

187. Id. at 862 (citing Lane v. Franks, 573 U.S. 228, 238-39 (2014)).

188. Id. at 861 .

189. Id. at 867 (internal quotation marks and citation omitted). 
matters of public concern. ${ }^{190}$

The Fourth Circuit, in a comparable case involving a police department's prohibition on unflattering comments on social media, likewise applied the NTEU standard and invalidated the policy. In Liverman v. City of Petersburg, two Virginia police officers who ran afoul of their employer for venting on Facebook about perceived inequities in their department's promotion policies challenged the "Negative Comments" policy under which they were disciplined. ${ }^{191}$ The policy stated, in pertinent part, "Negative comments on the internal operations of the [agency], or specific conduct of supervisors or peers that impacts the public's perception of the department is not protected by the First Amendment free speech clause, in accordance with established case law." 192

Officers Herbert Liverman and Vance Richards were reprimanded and put on disciplinary probation, disqualifying them from a round of promotion opportunities, after a string of back-and-forth Facebook posts complaining that inexperienced officers were receiving undeserved promotions and questioning the department's leadership. ${ }^{193}$ They challenged both the imposition of discipline and the policy itself as facially unconstitutional. ${ }^{194}$

The district court entered summary judgment for Liverman on his facial challenge to the policy, but dismissed all other claims. ${ }^{195}$ On appeal, the police department's counsel conceded that NTEU, not Garcetti, supplied the proper legal standard for analyzing a blanket policy restraining speech. ${ }^{196}$ Applying NTEU - and without reference to Lanethe Fourth Circuit found that the "Negative Comments" policy unconstitutionally restricted speech. ${ }^{197}$ Reversing the district court, the judges further found that the police chief could not claim qualified immunity from damages for imposing discipline, because the officers' First Amendment right to be free from viewpoint discrimination was clearly established. ${ }^{198}$

In short, there is no indication that federal courts widely understand

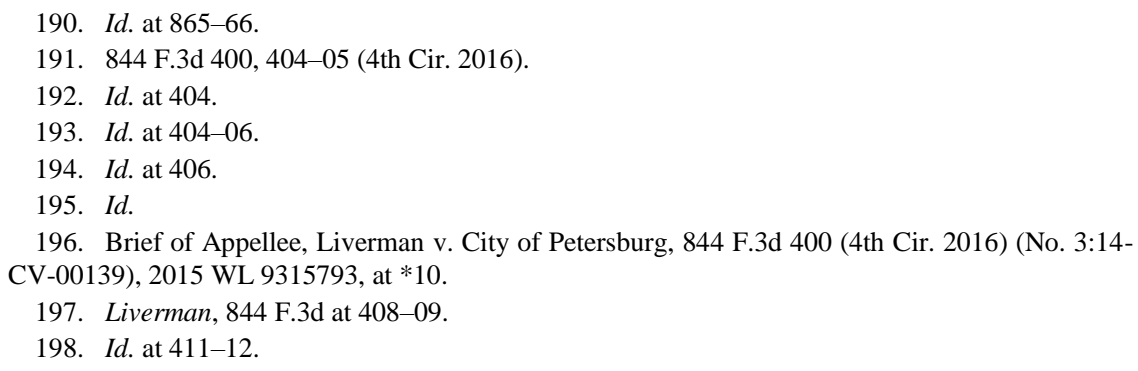


Garcetti to have legitimized broadly worded prohibitions against discussing workplace matters. To the contrary, such policies remain constitutionally infirm and vulnerable to facial challenge.

\section{UNBRIDLED DISCRETION AND THE FIRST AMENDMENT}

Even if a rule requiring employees to obtain supervisory approval before speaking with the media could survive a frontal challenge as a prior restraint forbidden by NTEU, additional First Amendment concerns remain. When a government agency imposes a permit or licensing system as a precondition for engaging in expressive activity, the system is unconstitutional if it fails to provide clear and objective standards to constrain the decisionmaker's discretion. ${ }^{199}$ Permitting systems that afford the regulator "unbridled discretion" are regularly invalidated. ${ }^{200}$

The Supreme Court first recognized in Hague v. Committee for Industrial Organization that open-ended permitting systems offend the First Amendment because they enable the decisionmaker to ration the right to speak based on subjective, and potentially viewpoint-discriminatory, considerations. ${ }^{201}$ The Hague case challenged the decision of a New Jersey police department to deny applications from Communist political groups to use a municipal meeting hall, relying on an ordinance that empowered the police chief to withhold a permit "for the purpose of preventing riots, disturbances or disorderly assemblage." 202 The Court struck down the permitting ordinance, finding that, without objective standards to constrain the police chief's exercise of authority, the ordinance could "be made the instrument of arbitrary suppression of free expression." 203

Similarly, in Cox v. Louisiana, the Supreme Court vacated a civil rights demonstrator's conviction on a charge of obstructing a public sidewalk, because the statute under which he was convicted gave "unfettered discretion" to municipal authorities to decide which uses of public property for expressive purposes were or were not punishable. ${ }^{204}$

199. See Nathan W. Kellum, Permit Schemes: Under Current Jurisprudence, What Permits Are Permitted?, 56 DRAKE L. REV. 381, 425 (2008) ("'A]uthoritative precedent supports the view that permit schemes should be limited in scope in all aspects and that any legitimate interest the government has pertains to public expression of such magnitude and attendance that, for the purposes of public safety and order, government regulation is deemed absolutely necessary.").

200. Id. at 398,414 n. 172 .

201. 307 U.S. 496, 515-16, 518 (1939).

202. Id. at $501,502 \mathrm{n} .1$.

203. Id. at 516 .

204. 379 U.S. $536,538-44,558$ (1965). 
Writing for the Court's 7-2 majority, Justice Arthur Goldberg found that the statute, while facially neutral, had in fact been applied in a

discriminatory way:

It is clearly unconstitutional to enable a public official to determine which expressions of view will be permitted and which will not or to engage in invidious discrimination among persons or groups either by use of a statute providing a system of broad discretionary licensing power or, as in this case, the equivalent of such a system by selective enforcement of an extremely broad prohibitory statute. ${ }^{205}$

To be constitutional, any permitting system imposed as a condition of speech must cabin the decisionmaker's discretion with "neutral criteria to insure that the licensing decision is not based on the content or viewpoint of the speech being considered." 206

Gag policies restricting public employees' communications with news media rarely, if ever, offer any standards assuring the speaker that permission to speak will be granted without regard to content or viewpoint. Indeed, the desire to prevent employees from speaking about subjects their supervisors regard as sensitive, controversial, or unfavorable to the image of the agency is at times overtly the purpose of the restriction. Then-Judge Alito's opinion for the Third Circuit invalidating a prior-restraint policy constraining Pittsburgh police officers' speech found the policy to be "so open-ended that it creates a danger of improper application." 207 Judge Alito stopped short of saying that restrictions on employee speech must be scrutinized with the same "degree of precision" that Cox and City of Lakewood applied to permitting regimens, but nevertheless found the absence of any limiting principles for the police department's exercise of discretion "disturbing." "208

A Rhode Island district judge likewise found a police department's pre-approval requirement to be infirm, because it gave supervisory

\footnotetext{
205. Id. at 557-58.
}

206. City of Lakewood v. Plain Dealer Publ'g Co., 486 U.S. 750, 753, 760 (1988) (following Cox and striking down a permitting system that gave the city manager unfettered discretion to permit or deny the placement of newspaper racks on city property); see also Thomas v. Chi. Park Dist., 534 U.S. 316, 323 (2002) ("Where the licensing official enjoys unduly broad discretion in determining whether to grant or deny a permit, there is a risk that he will favor or disfavor speech based on its content." (citation omitted)); Trey Hatch, Keep on Rockin' in the Free World: A First Amendment Analysis of Entertainment Permit Schemes, 26 ColuM. J.L. \& ARTS 313, 320-21 (2003) (explaining that, to be constitutional, a licensing system "must not grant unbridled discretion to decision-makers, but rather must incorporate narrow, objective, and definite standards or limits to guide their decision").

207. Swartzwelder v. McNeilly, 297 F.3d 228, 231, 240 (3d Cir. 2002).

208. Id. 
officials complete discretion to grant or deny permission for an officer to speak to the media about any work-related matter. ${ }^{209}$ In addition to being unconstitutionally overbroad, the order was vulnerable to a First Amendment challenge because it "sets no standards to guide the decisionmaking process, does not require any explanation for a denial of permission to speak, and proposes no time frame for such grant or denial." 210

Applying City of Lakewood, a federal district court in Ohio struck down a municipal fire department's external communications policy as facially unconstitutional. ${ }^{211}$ The policy — which stated that fire department officers "may not publicly communicate on matters concerning Mansfield Fire Department rules, duties, policies, procedures and practices without ... prior written approval"-flunked First Amendment scrutiny because it failed to provide "narrow, objective and definite standards" governing whether employees would be permitted to speak. ${ }^{212}$

Of the more than 150 federal, state and local-government policies examined by Brechner Center researchers in compiling this paper, none contained any standards by which an agency decision maker would decide whether to grant or deny an interview request. None of the policies provided a time deadline for consideration of requests, or specified any route to appeal an adverse decision if the speaker was aggrieved by the denial. Standard government policies, in other words, provide none of the objective and neutral criteria that federal courts regard as imperative for a speech-restrictive permitting system to be constitutional.

Whether the same skeptical review that applies in the more traditional "permitting" context applies with equal force in the workplace or not, the same policy concerns are at play: government officials with unfettered discretion to grant or deny permission to speak will be tempted to use that discretion in viewpoint-discriminatory ways. For this additional reason, policies requiring public employees to seek approval before discussing their work with journalists are unlikely to survive constitutional scrutiny.

209. Kessler v. City of Providence, 167 F. Supp. 2d 482, 489 (D.R.I. 2001).

210. Id. at 489-90.

211. Spain v. City of Mansfield, 915 F. Supp. 919, 923 (N.D. Ohio 1996).

212. Id. at 922-23 (citing City of Lakewood v. Plain Dealer Publ'g Co., 486 U.S. 750, 763 (1988)). The former assistant fire chief also challenged the policy as applied, alleging he was "forced to retire in retaliation for" speaking without authorization about several department governance matters. Id. at 923-24. Applying a Pickering balancing analysis, the court found in favor of the plaintiff and declined the city's motion for summary judgment. $I d$. 


\section{GAG ORDERS: PERVASIVENESS AND IMPACT}

When a Nevada State Patrol supervisor was sued over an email directive requiring employees to get approval before discussing certain work-related matters with the public, the supervisor defended himself by showing just how frequently law-enforcement agencies-including his own-restrict their employees' speech. ${ }^{213}$ Pointing to a State Patrol policy that requires approval before releasing any information about the agency, the supervisor's attorneys argued that, if his email was an unlawful prior restraint, "then this confidentiality policy is too. And if [this] policy is, then confidentiality policies maintained by police and sheriff offices in thousands of cities within the Ninth Circuit are vulnerable to attack as illegal 'prior restraints,' a First Amendment violation so hateful as to be virtually outlawed." 214

The court in the Nevada patrolman's case, Moonin v. Tice, was not persuaded by this argument. ${ }^{215}$ Agency policies restraining employee speech are as unremarkable as violations of the fifty-five-mph speed limit. However, like speeding on the highway, rampant disobedience of the law is not a legal defense.

In Wisconsin, reporters with the Lee Enterprises newspaper chain examined the policies of twenty state agencies in 2016 and found that just two expressly authorized their employees to speak at will to journalists, while five other agencies allowed employees to field only certain types of requests. ${ }^{216}$ The remaining thirteen out of twenty agencies filtered all interactions with the news media through a public-relations office; one agency directed employees to write down questions received from journalists and email them to a media-relations officer to be answered; and another provided a script for employees to read if contacted by a reporter directing all inquiries to the agency communications director. ${ }^{217}$ Agency communications officers questioned about their policies invariably gave comparable responses: funneling calls from journalists to a publicrelations professional ensures that the journalist will be referred to the

213. Reply Brief of Defendant-Appellant, Moonin v. Tice, 868 F.3d 853 (9th Cir. 2017) (No. 1516571), $2016 \mathrm{WL} 4055435$, at *3.

214. Id. at *11.

215. 868 F.3d 853 (9th Cir. 2017).

216. Chris Hubbuch, Special Treatment or Limited Access? State Government Policies Dictate Who Can Talk to the Press, ChIPPEwa HeRALD (Mar. 13, 2016), https://chippewa.com/specialtreatment-or-limited-access/article_4edc5f57-787d-50d3-bb35-2b4c1bc1926b.html [https://perma.cc/36PS-76ZQ].

217. $I d$. 
most knowledgeable employee. ${ }^{218}$

A pair of surveys of political reporters, one completed in 2012 by journalists covering federal agencies and another completed in 2014 by journalists assigned to state and local agencies, indicates that "gatekeeping" by government public-relations offices is widespread. ${ }^{219}$ About eighty-five percent of federal reporters and seventy-six percent of state-and-local reporters agreed with the researchers' survey statement: "The public is not getting all the information it needs because of barriers agencies are imposing on journalists' reporting practices."220 Questioned on an agree/disagree scale with five signifying strongest agreement and one signifying strongest disagreement, local reporters' agreement scored a 3.47 and federal reporters' agreement scored 3.92 to the statement: "I am required to obtain approval from the agency public information officer before interviewing agency employees." 221

The inability of journalists to get direct access to news sources became such a persistent source of frustration to journalists that, in 2017, the Society of Professional Journalists ("SPJ") adopted a resolution at its annual national convention denouncing what SPJ called "mandat[ory] clearance culture," stating that "restrictions on access pose a grave risk to the public welfare."222 The resolution followed a series of unsuccessful attempts to persuade the Obama White House to loosen constraints on federal employees and end the involvement of agency public-relations managers in pre-approving and monitoring interviews. ${ }^{223}$

While doubtfully legal, wholesale prohibitions on unapproved media interviews persist across all levels of government. Researchers from the Brechner Center searched online through the published media-relations policies of hundreds of federal, state, and local agencies, and found dozens that run afoul of the standard established by the Supreme Court in NTEU and the lower-court cases applying it. ${ }^{224}$

218. Id.

219. Carolyn S. Carlson \& David Cuillier, Public Information Officers Exert Increasing Controls, 38 NEWSPAPER RES. J.198, 206 (2017).

220. Id. (internal quotation marks omitted).

221. Id. at 204.

222. Soc'y of Prof'l Journalists, Res. No. 2, Calling on Journalists to Oppose the Mandated Clearance Culture (2017), https://www.spj.org/res2017.asp\#2 [https://perma.cc/3FWG-9EHL].

223. See, e.g., Letter from Dana Neuts, President, Society of Professional Journalists, et al., to President Barack Obama (Aug. 10, 2015), http://spj.org/pdf/news/obama-letter-final-08102015.pdf [https://perma.cc/G4SN-B9YV].

224. UNIV. OF Fla., BRECHNER CENTER FOR FREEDOM OF INFORMATION, PROTECTING SOURCES and Whistleblowers: The First Amendment and Public EMPloyeES' Right to SPEAK to the MEDIA 11-12 (2019) [hereinafter BRECHNER CENTER REPORT]. 


\section{A. Gag Policies at Federal Agencies}

Constraints on federal employee speech did not originate with Donald Trump's election in 2016. In a 2008 report, the Union of Concerned Scientists ("UCS") examined the media policies of fifteen federal agencies with an eye toward whether federal scientists could freely talk to the media about their areas of expertise without interference from agency management. ${ }^{225}$ The report found a range of agency practices, both formal and informal, that interfered with employees' ability to have unfiltered access to journalists - although only one, the Consumer Product Safety Commission, actually published a nationwide policy requiring employees to route all media contacts to the agency's public-relations office. ${ }^{226}$ Around the same time, the New York Times reported that federal immigration judges, who are appointed by the Justice Department, were under orders not to speak to the media. ${ }^{227}$

During 2010, an employee-rights watchdog group obtained and published a directive from the head of public relations for the Monongahela National Forest, who told agency employees:

[W] remain under strict instructions for talking with the media. So, a reminder: If you receive media calls that fall under the following categories you cannot talk to the reporter, but should instead get their contact info and get in touch with me: 1 . contacts by a member of the national media on ANY subject 2. contacts by a local or regional reporter seeking information about a national issue including policy and budget issues. ${ }^{228}$

During the Obama administration, Washington Post reporters encountered restrictive agency policies when trying to report on the struggle to reduce patient wait times at Veterans Administration ("VA") hospitals. ${ }^{22}$ The Post heard from several VA physicians who reported that

225. Union of CONCERNEd SCIENTISTS: Citizens AND SCIENTISTS FOR ENVIRONMENTAL

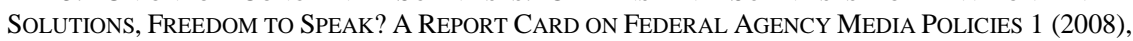
http://www.ucsusa.org/sites/default/files/legacy/assets/documents/scientific_integrity/Freedom-toSpeak.pdf [https://perma.cc/8J3V-ARA4].

226. Id. at 3 .

227. Charlie Savage, Vetted Judges More Likely to Reject Asylum Bids, N.Y. Times (Aug. 23, 2008), https://www.nytimes.com/2008/08/24/washington/24judges.html [https://perma.cc/6L598SXU] ("Judge Wilson, who previously worked in the Office of Immigration Litigation at the Justice Department, said he was not allowed to give interviews.").

228. Kate Goodrich-Arling, Obama Gag Order on Federal Workers Like Those Under Bush, PEER (Jan. 28, 2010), https://www.peer.org/assets/docs/fs/1_28_10_FS_Media_gag_order.pdf [https://perma.cc/29KS-364J] (quoting the Public and Legislative Affairs Officer's email to Monongahela National Forest employees).

229. Emily Wax-Thibodeaux, It Was Meant to Reduce Wait Times, but Veterans Say New Choice 
a patient "benefits card" meant to expedite treatment was causing confusion among patients and providers that actually delayed treatment. ${ }^{230}$ But the Post was unable to quote any of the doctors by name "because VA employees are not allowed to speak to the media without permission."231

Public attention to federal employees' free-speech rights intensified after Trump assumed the presidency in January 2017, both because the constraints played into a larger narrative of Trump's hostility toward the news media and because the constraints were perceived as part of a strategy to undercut authoritative discussion about climate change. The open-government nonprofit, Sunlight Foundation, documented a wave of directives issued across federal agencies around the time of Trump's inauguration instructing federal employees to cease responding to requests for information, posting information to social media, or otherwise making statements to the public about agency business without express orders from the new administration. ${ }^{232}$

Agency policies often are ambiguous and could reasonably be interpreted to require pre-approval of all interactions with the news media, a practice that federal courts have declared unconstitutionally broad. Guidelines issued by the Department of Health and Human Services as the Trump administration took office emphasize that subject-matter experts within the agency should be made accessible for interviews, but goes on to say:

In order to make certain we provide the media the best possible service and information in a timely fashion, it is important that the relevant agency public affairs office be notified of all media calls/contacts that employees receive about their HHS work.

Reporters should be informed that the agency's public affairs office coordinates media requests to ensure they receive requested information within their deadline. The primary objective for routing reporter calls to the agency public affairs office is to ensure an effective, timely and coordinated agency and departmental response. ${ }^{233}$

Cards Are Causing More Problems, WASH. POST (Feb. 16, 2015), https://www.washingtonpost.com /news/federal-eye/wp/2015/02/16/it-was-meant-to-reduce-wait-times-but-veterans-say-new-choicecards-are-causing-more-problems/ [https://perma.cc/HG5V-CGGN].

230. Id

231. Id.

232. Reports of Federal Government Agencies Directed Not to Communicate with the American Public, SunLIGHT FOUND. (2017), https://sunlightfoundation.com/list-of-federal-government-agencie s-told-not-to-communicate-with-the-public/ [https://perma.cc/6H3E-DHTB].

233. U.S. DEP'T OF HEALTH \& HuMAN SERVS., GUIDELINES ON THE PROVISION OF INFORMATION TO THE NEWS MEDIA 4 (Jan. 2017), https://www.hhs.gov/sites/default/files/media_policy.pdf [https://perma.cc/337G-6AX2]. 
The reference to "routing" reporters through the public-affairs coordinator leaves the strong impression that it is mandatory for employees to seek clearance from a public-relations officer before replying to a journalist's query.

Even where agencies' policies, on paper, appear compliant with the NTEU standard, they may operate very differently in practice. Scientific American reported that, although the U.S. Centers for Disease Control and Prevention ("CDC") tells employees not to seek "clearance" from the CDC public-relations office before providing information to reporters, the CDC policy was undercut by an August 2017 email memorandum from a CDC administrator. ${ }^{234}$ The email, first published by the news organization Axios, told employees:

Effective immediately and until further notice, any and all correspondence with any member of the news media, regardless of the nature of the inquiry, must be cleared through CDC's Atlanta Communications Office.... This correspondence includes everything from formal interview requests to the most basic of data requests. ${ }^{235}$

Columbia Journalism Review called the apparent shift in accessibility of CDC experts part of "an expanding information blockade" under the Trump administration that affected all health- and science-related agencies. $^{236}$

\section{B. Gag Policies at State Agencies}

Agencies of state government frequently instruct their employees that they are forbidden from unapproved interactions with journalists, making no distinction between communications in an official (Garcetti) capacity as part of official duties versus communications as an individual addressing a matter of public concern. Brechner Center researchers found broadly speech-restrictive policies readily available on the websites of dozens of state government agencies across the country and obtained others by way of freedom-of-information requests for agency manuals,

234. Charles Seife, In Washington Speak, Censorship is Called "Transparency," SCI. AM. (Jan. 10, 2018), https://www.scientificamerican.com/article/in-washington-speak-censorship-is-called-ldq uo-transparency-rdquo/ [https://perma.cc/U6DR-2GU8].

235. Sam Baker, CDC Cracks Down on Communications with Reporters, Axios (Sept. 12, 2017), https://www.axios.com/cdc-cracks-down-on-communications-with-reporters-15133054430a94d025-172c-44f1-b26c-e02885bdff40.html [https://perma.cc/CD86-ZDUC].

236. Trudy Lieberman, CDC Official Sends Troubling Message to Employees About Media Questions, COLUM. JOURNALISM REV. (Sept. 13, 2017), https://www.cjr.org/covering_the_health_car e_fight/cdc-health-reporters-journalism.php [https://perma.cc/DK25-U2VF]. 
handbooks, or employment contracts. ${ }^{237}$

The Georgia Department of Juvenile Justice, an agency of more than 2,300 employees working at twenty-six facilities and ninety-seven community services offices throughout the state, instructs:

Any employee who receives a media inquiry must: 1 . Refer the inquirer to the Office of Communications; and 2. Promptly notify the Office of Communications through his/her chain of command.

Staff may not contact media, furnish information to the media, or speak on behalf of the Department without prior approval of the Director of Communications, Assistant Commissioner, or Commissioner. ${ }^{238}$

A sister agency, the Georgia Department of Public Health, instructed its employees in a Media Relations Policy memorandum dated September 2014: "DPH employees should not respond to requests for information from the news media in any capacity.... All media inquiries must be referred to the Communications Division." 239 The qualifier "in any capacity" clearly constrains employees from engaging in constitutionally protected expression that is not made pursuant to official duties.

Regulations governing employees of Maryland's state prison division provide: "An employee of a Division facility shall refer all media inquiries to the warden. The warden shall determine whether media inquiries will be forwarded to the Public Information Office of the Division." ${ }^{240}$ In Montana, similarly, prison employees are told to "refer all media inquiries about official MSP business to the PIO or Warden," and not to speak to the media "unless specifically requested to do so by the Warden or the PIO." 241

Journalists covering state government regularly report that they have been told employees are off-limits to be interviewed, though it is frequently unclear whether the restraint carries the force of a formal regulation or is merely a workplace norm. Amid a swirl of media attention

237. BRECHNER CENTER REPORT, supra note 224, at 11-12.

238. Ga. DeP't of Juvenile Justice, Policy No. 1.8: Public Information 2 (Dec. 28, 2017), http://www.djj.state.ga.us/Policies/DJJPolicies/Chapter01/DJJ1.8PublicInformation.pdf [https://perm a.cc/NCV3-6349].

239. Ga. Dep't of Pub. Health, Media Relations Policy No. CM-07002 5 (Sept. 14, 2014), http://publichealthathens.com/wp/wp-content/uploads/2014/09/CM-07702-Media-Relations19Sept2014.pdf [https://perma.cc/3YQ4-JPG8].

240. MD. Code REgS. 12.02.04.03(A)(2)-(3) (2019).

241. Mont. Dep'T of Corr., Montana State Prison Operational Procedure No. 1.1.8: Media RELATIONS 2 (Aug. 22, 2017), https://cor.mt.gov/Portals/104/Resources/Policy/MSPprocedures/1-1-8Medi aRelations.pdf [https://perma.cc/XR39-6BFE]. 
to sexual harassment in state legislatures across the country, the chief of staff for the Colorado Senate distributed a memo reminding Senate staffers that, unless approved by Senate leadership, "no Senate employee, including aides, interns and volunteers may grant interviews to the press." ${ }^{242}$ A teacher working in a Florida prison who was asked about her working conditions told the New York Times that employees are "not authorized to speak to the news media."243

Some agencies do make an effort to distinguish between employee communications in an official capacity on behalf of the employer versus speech in an individual capacity. The Arizona Department of Corrections, for instance, tells employees that only designated high-ranking officials are authorized to speak to the media "on behalf of the Department," but then goes on to say that "[a]ny Department employee may speak with the media about personal issues or to express their personal opinions about Department operations in general on their own time." 244

\section{Gag Policies in the Law Enforcement Setting}

State and local law-enforcement agencies have been the source of most of the employee-speech litigation over the past half-century, yet they persist in threatening to sanction employees caught discussing workrelated information without approval.

A policy manual for the Florida Department of Highway Safety and Motor Vehicles instructs Highway Patrol employees that they "must not discuss department matters with the media" unless speaking to journalists is part of their official job duties or they are instructed to do so by the agency's executive director or communications director. ${ }^{245}$ The Texas Department of Public Safety tells its officers that "all media contacts received by DPS employees shall be immediately forwarded" to the agency's Media and Communications Office, with the sole exception that

242. Bente Birkeland, Emails Warn Workers at Colorado Capitol Not to Speak to Press, KUNC (Mar. 13, 2018), https://www.kunc.org/post/emails-warn-workers-colorado-capitol-not-speak-press\# stream/0 [https://perma.cc/AM4H-36TK]. The chief of staff's instruction was in line with the Senate Employee Handbook's instructions on media relations. Id.

243. Danielle Ivory \& Caitlin Dickerson, Safety Concerns Grow as Inmates are Guarded by Teachers and Secretaries, N.Y. TiMES (June 17, 2018), https://www.nytimes.com/2018/06/17/us/prisons-safety-substi tute-guards.html [https://perma.cc/593Q-YS2L].

244. Ariz. DeP'T of Corr., Department Order Manual, Order 207: Media Relations 1, 3 (Mar. 25, 2013), https://corrections.az.gov/sites/default/files/0207_0.pdf [https://perma.cc/LYA6R43U].

245. Fla. Highway SAFETy \& MOtor Vehicle, Policy No. 8.09: SUbJECt InTERACTION With MEDiA ORGANIZATIONS 2-3 (Mar. 26, 2018), https://www.flhsmv.gov/pdf/policies/0809.pdf [https://perma.cc/L8J7-TD9H]. 
officers on the scene of a traffic incident may furnish "general information" if a public-information officer is unavailable. ${ }^{246}$ A policy manual for the New Jersey State Police authorizes officers to speak to the media only about the basic facts of "routine" matters concerning traffic incidents and minor crimes, but otherwise requires that all "non-routine" communications with the media be filtered through the agency's public information office. ${ }^{247}$ The definition of "non-routine" information that may not be discussed with the news media without approval explicitly includes "[i]nquiries about policies, procedures, personnel, etc.," adding that officers may not offer "comments, opinions, assumptions, sarcasm, or language that may be interpreted in a way contrary to the intent of the speaker." "248 In Utah, officers of the Department of Public Safety "are required to coordinate any and all news media requests through the department PIO" and are typically permitted to speak to the media "after coordinating with the PIO." 249

Comparable policies abound at city and county-level police agencies. Officers in Buffalo, New York, told a reporter investigating the death of a pedestrian run over by a police cruiser that they were not authorized to speak to the media. ${ }^{250}$ The rulebook for police officers in Framingham, Massachusetts, states that "[a]ny officer may give information to media personnel with prior approval from the P.I.O. or the Chief." ${ }^{251}$ In the town of Truro, Massachusetts, the published handbook for police officers states that only specified high-ranking officers may release information to the media or others outside the department. ${ }^{252}$ The Fairfax Police Department in Virginia requires that the agency's Media Relations Bureau "approve any request for a Departmental employee to be interviewed by any media

246. TeX. DeP’T OF Pub. SAFETy, Policy No. 21.02.01, Rule § 1.51: Media INQUiRIES (obtained through FOIA request) (on file with author).

247. N.J. State Police, Standard Operating Procedure \# B6: Public Information and MEDia RELATIONS 2-3 (Feb. 23, 2007) (obtained through FOIA request) (on file with author).

248. Id. at 2.

249. E-mail from Sgt. Nicholas Street, Utah Highway Patrol Public Information Officer, to author (May 29, 2019) (on file with author).

250. Lou Michel, New Details Emerge in North Buffalo Police Crash that Killed Woman, BufFalo News (Apr. 4, 2018), https://buffalonews.com/2018/04/04/new-details-emerge-in-buffalopolice-crash-that-killed-woman/ [https://perma.cc/TY8D-PQ5X].

251. Town of Framingham Police Dep’t, Policy on Police Media Relations \#50-1 3 (Sept. 4, 2014), https://framinghamma.gov/DocumentCenter/View/21392/Police-and-Media-Relations [https://perm a.cc/6FVN-KHMW].

252. Truro Police Dep'T, Media Relations Policy No. OPS-8.02 2 (Apr. 15, 2001), http://www.truropolice.org/On\%20Line\%20Manuals/Media\%20Relations.pdf [https://perma.cc/P3H L-RDTB]. 
outlet." ${ }^{253}$ None of these policies are reconcilable with NTEU or more than a dozen lower-court cases applying the NTEU standard in the context of public-safety agencies, demonstrating that government policymakers either widely misunderstand or widely ignore their legal obligations when it comes to employee speech rights.

Indeed, even the Nevada Highway Patrol - the agency that just lost a First Amendment challenge to overly restrictive employee-speech policies in $2017^{254}$ - still appears to have such policies in force. As part of a fiftystate survey of state police agencies conducted during March and April 2019, Brechner Center researchers asked the Nevada Department of Public Safety for its current policy on employee communications with the news media. $^{255}$ In response, the agency produced four pages from a departmental policy manual dated 2018 - the year after the adverse ruling from the Ninth Circuit-stating in pertinent part: "At no time shall any employee of this Department make any comment or release any official information to the media without prior approval from a supervisor or the designated Department media representative." 256 That policy bears the imprint of a commercial vendor of policy handbooks, and the same wording can be found at police agencies across the country using the same vendor, including those in Peoria, Arizona; ${ }^{257}$ Urbana, Illinois; ${ }^{258}$ Pittsfield, Massachusetts; $;^{259}$ and West Valley City, Utah. ${ }^{260}$

\section{Gag Policies by Colleges and K-12 Schools}

Broad restrictions on employee speech are routine at public higher

253. Fairfax Cty. Police DeP’t, General ORder: Media Relations BuREau 5 (Dec. 10, 2018), https://www.fairfaxcounty.gov/police/sites/police/files/assets/images/chief/generalorders/401\%20$\% 20$ media\%20relations\%20bureau.pdf [https://perma.cc/XPL6-EPPF].

254. Moonin v. Tice, 868 F.3d 853 (9th Cir. 2017).

255. BRECHNER CENTER REPORT, supra note 224, at 11.

256. Nev. Dep’t of Pub. Safety, Policy No. 326.2.1: News Media Relations (2018) (obtained through FOIA request) (on file with author).

257. Peoria Police DeP’t, Peoria PD Policy Manual: Policy No. 346.2.1: Media ReQuest (2017), https://www.peoriaaz.gov/Home/ShowDocument?id=4600 [https://perma.cc/36JV-JXN9].

258. Urbana Police Dep'T, Policy Manual: Policy No. 326.2.1: Media ReQuest (Dec. 30, 2015), https://www.urbanaillinois.us/sites/default/files/attachments/326-media-relations.pdf [https://perma.cc/HS29-9ZQD].

259. Pittsfield Police DeP'T, Policy Manual: Policy No. 324.5: Media ReQuests (Dec. 12, 2018), http://www.pittsfieldpd.org/wp-content/uploads/2019/01/324-Media-Relations-2018.pdf [https://perma.cc/S25S-AFYE].

260. W. Valley City Police Dep’T, Policy Manual: Policy No. 346.2.1: Media Request (Sept. 15, 2014), https://www.wvc-ut.gov/DocumentCenter/View/11639/WVCPD-Policy-Manual-11 012016? bidId= [https://perma.cc/4YTG-XMUN]. 
educational institutions. ${ }^{261}$ Employees regularly are told, without exception, that all communications with the news media must be filtered through an institutional public-relations or marketing office. A policy posted by Southern Illinois University-Edwardsville is typical:

If you are contacted by a member of the media, you should refer the inquiry to University Marketing and Communications (UMC) for an official statement .... If you are needed as a subject matter expert, we will coordinate schedules, assist you in developing talking points and prepare you for the interview. ${ }^{262}$

The University of Maryland-Baltimore College provides in its mediarelations policy, which carries the approval of a university vice president, that "[a]11 media communications must be channeled through either the Associate Vice President for Communications or the Director of Media Public Relations in the Office of Communications."263 The media policy at the University of Alabama-Birmingham requires employees who are contacted by journalists to "immediately" notify the Office of University Relations, directs reporters to contact the University Relations office for approval to interview employees, and-for good measure-threatens reporters with removal from campus by police if they enter the premises without approval from University Relations authorities. ${ }^{264}$ In addition to blanket campus-wide gag policies, athletic departments commonly enforce even more rigid controls over interactions with journalists, both by members of the coaching staff and by student-athletes. ${ }^{265}$ This results

261. In an especially peculiar variant, the University of Texas-San Antonio ("UTSA") states that "UTSA students, faculty and staff members, friends and visitors are prohibited from issuing official university statements, without the expressed written permission of the Chief Communications Officer," as if statements made by "friends" or "visitors" would be taken as official statements on behalf of the university. UNIV. OF TEXAS-SAN ANTONIO, HANDBOOK OF OPERATING PROCEDURES, RULE 4.22: UNIVERSITY MARKETING, BRANDING AND COMMUNICATIONS § IX(J) (Dec. 21, 2017), http://www.utsa.edu/hop/chapter4/4-22.html [https://perma.cc/U62E-EKL4].

262. S. Ill. Univ.-Edwardsville, Public Information \& Media Relations: Handling MEDIA INQUIRIES, https://www.siue.edu/marketing-and-communications/services/media-relations/ha ndling-media-inquiries.shtml [https://perma.cc/G27E-YWG3].

263. Univ. OF Md., Policy 570.10: Public Relations (Sept. 16, 2002), https://www.umuc.edu/administration/policies-and-reporting/policies/external-relations/publicrelations.cfm [https://perma.cc/D5WC-RCHQ].

264. Univ. of Ala. AT BiRmingham, Media Policy Guidelines 2-5 (Nov. 2015), https://www. uab.edu/news/images/Media_Policy_Guidelines_11302015.pdf [https://perma.cc/QE3N-BN2B].

265. See, e.g., Jake Elman, Lane Kiffin's FAU Owls Take Page from Alabama to Help Beat Down Rivals, PALM BEACH POST (Nov. 1, 2017, 12:01 AM), http://gm5-lkweb.newscyclecloud.com/sports/collegefootball/lane-kiffin-fau-owls-takes-page-from-alabama-help-beat-down-rivals/8J27A8NMRDHqnN8NaH EdVJ/[https://perma.cc/6L77-BRGB] (reporting that assistant football coaches at Florida Atlantic University are forbidden from speaking to the media); Ross Dellenger, LSU's Derrius Guice Runs for Murdered Father, Hard-Working Mom, Hard-Driving Coaches, ADVOC. (Oct. 19, 2015, 8:22 AM), https:// 
in the bizarre anomaly that news stories about noteworthy athletes often must be written without comments from the athletes.

Constraints on employee speech are commonplace at two-year institutions as well. Arizona's Pima Community College published a directive to employees in 2015 instructing them to refer all media inquiries to the college's public-relations office. ${ }^{266}$ The policy states, in pertinent part: "Notify us immediately if you receive a media inquiry, and do not grant an interview or provide any information." 267 Texas's San Jacinto College instructs employees, "[a]11 media relations requests and actions flow through the Marketing, Public Relations, and Government Affairs department," and that if contacted by a reporter, "the employee should direct the reporter to the Vice President, Marketing and Public Relations."268 The policy also directs employees to notify college management if they see a news photographer or videographer on the campus unaccompanied by a public-relations representative. ${ }^{269}$ A sister two-year institution in Texas, Panola College, states in its Media Interviews policy: "Employee [sic] who are contacted by a reporter and have not received a media referral notice from the Office of Institutional Advancement must refer the reporter's request back to the Office of Institutional Advancement," and also provides that any reporter on campus who has not been "cleared" must be reported to college authorities. ${ }^{270}$

Even where institutions stop short of making it a punishable offense to speak to the media without approval, their policies may create the impression that unapproved interviews are forbidden. For instance, the University of Houston's news media policy provides that "all media inquiries should be channeled through the Office of University Media Relations," and goes on to state that "[w]hen an employee or department

www.theadvocate.com/baton_rouge/sports/lsu/article_9b871504-3179-5cd7-80f8-a8a4aeb2ea96.html [https://perma.cc/4FJT-AATZ] (profiling a prodigious Louisiana State University recruit without quotes from him, because LSU does not allow freshmen to speak with the media); Mark Cooper, Small-Town OSU Freshman James Washington is Making a Big Impression, TUlSA WORLD (Aug. 13, 2014), https://www.tulsaworld.com/sports/college/osu/small-town-osu-freshman-james-washington-is-making-abig/article_effcd3e2-083c-5868-b57c-fe4b8122eea2.html [https://perma.cc/AXV7-SFZS] (chronicling exploits of high-achieving Oklahoma State University football star who, because of athletic department policies, was not allowed to give an interview).

266. Carol Ann Alaimo, New PCC Policy Bans Employees Talking to Media, ARIZ. DAILY STAR (Oct. 3, 2015), http://tucson.com/news/local/education/new-pcc-policy-bans-employees-talking-tomedia/article_f26e4ad4-d215-5152-b76c-472e51c397dc.html [https://perma.cc/KAE4-UY76].

267. Id.

268. San Jacinto C., Procedure VII.7001.A.a, Public Relations (Feb. 6, 2018), https://www.sanjac.edu/procedure-vii7001aa-public-relations [https://perma.cc/93DZ-8GYS].

269. Id.

270. Panola Coll., Visual Communication Guide: Media Interviews, https://www.panola. edu/faculty-and-staff/visual-comm-guide/interviews.html [https://perma.cc/S9JL-4MV4]. 
is contacted by the news media, he/she is strongly encouraged to notify University Media Relations immediately, before providing any information or responding to questions." encouraged" admonition appears in a comparable policy disseminated by the University of Southern Indiana. ${ }^{272}$ Many other institutions maintain restrictive policies about speaking to the media only at times of "emergency" or "crisis." A prototypical example is on the books at the University of Louisville, which tells its employees: "No one is authorized to speak to the news media in a crisis without clearance from the Office of Communications and Marketing." ${ }^{273}$ Similarly, Montana State University identifies categories of "sensitive" or "controversial" issues that employees should not address with the news media, including "1) legal issues, 2) personnel issues, 3) questions that involve university integrity, such as ethics or issues that may result in harm to others, or 4) a campus crisis or emergency." ${ }^{274}$ A comparable policy at Texas State University enumerates seven categories of media query that must be referred to the Office of Media Relations, among them: inquiries about "a universitywide matter or policy," questions about "a controversial or sensitive matter," and inquiries about "a matter of proposed or alleged university policy." 275 While perhaps more defensible than absolute prohibitions, these category-specific policies also invite challenge as overbroad or viewpoint-discriminatory, since subjects such as "ethics" or "university integrity" may be topics on which employees have opinions they care to share as individuals.

Some institutions more carefully tread the First Amendment line,

271. Univ. of Hous., University Marketing, Communications and Media Relations, News MEDIA POLICY, https://www.uh.edu/marcom/guidelines-policies/news-media/index [https:// perma.cc/J4DM-PX4R].

272. Univ. of S. Ind., University Communications: News Media Policy, https://www.usi. edu/news/news-media-policy [https://perma.cc/4HEL-6CKK].

273. Univ. of LOUISVILle, OfFice of Univ. AdVANCEMENT, CRisis COMMUNiCATION AT THE UNIVERSITY OF LOUISVILLE: POLICIES AND PROCEDURES, http://php.louisville.edu/advancement/ocm/crisis _comm/ [https://perma.cc/8JBR-KLPM]. The policy defines a "crisis" situation as: "A significant disturbance in the university's activities which results in extensive news coverage and public scrutiny, and which has the potential to cause long-term public relations damage," which makes apparent that the policy is not limited to cases of danger to physical safety but also includes danger to the college's reputation. Id.

274. Mont. State Univ., Media Policy Guidelines, § 200.00: General Procedures for DEALING WITH THE MEDIA, https://www.montana.edu/policy/media_policy/ [https://perma.cc/89U7-GC $\mathrm{KC}$. The Montana State policy is noteworthy because it singles out faculty employees and staff for preferred status, freeing them to speak to the media about matters within their expertise but making no such provision for non-teaching employees. Id.

275. Tex. State Univ., Policy and Procedure Statements: Responding to Media INQUIRIES $\S 04.01$ (c) (June 22, 2017), https://policies.txstate.edu/university-policies/06-05-02.html [https://perma.cc/QN6X-4EBK]. 
asserting control over employees' speech only when they are acting in an official capacity addressing matters of institutional policy. Texas Tech University, for instance, tells faculty they are "encouraged" to speak directly to news organizations about their subject-matter expertise, and suggests - but does not require - that employees seek assistance from the university communications office if faced with a question "of a controversial or a questionable nature." ${ }^{276}$ It is also common for universities to carve out a more-protected status for faculty speakers as opposed to non-teaching employees, referencing norms of "academic freedom" that are recognized as affording faculty a measure of autonomy in matters of teaching and research. ${ }^{277}$ For example, the University of Maine includes a disclaimer in its news-media policy that "faculty may respond to media inquiries directly on matters related to their professional duties, the functioning of the university, and/or on matters of public concern," subject to Pickering-type standards. ${ }^{278}$ While this type of policy ameliorates some of the harsher effects of gag policies, it does nothing for the police officer, bookstore cashier, or the many other non-teaching employees on college campuses who have First Amendment rights comparable to, if not equal to, those of faculty. ${ }^{279}$

The muzzling of college employees has received more media attention than at other levels of government, likely owing to a larger national focus on the state of free speech on college campuses. ${ }^{280}$ Heavy-handed control

276. Tex. Tech Univ., Operating Policies \& Procedures § 5: Responding to Media INQUIRIES (Apr. 27, 2017), https://www.depts.ttu.edu/opmanual/OP68.01.php [https://perma.cc/4JF5SJQ6].

277. See generally Neal H. Hutchens, A Confused Concern of the First Amendment: The Uncertain Status of Constitutional Protection for Individual Academic Freedom, 36 J.C. \& U.L. 145 (2009) (explaining that courts disagree whether the Constitution affords professors freedom to teach as they choose or whether the "right" belongs only to their institutional employer).

278. Univ. OF Me., Div. OF MKtg. ANd Commc'Ns, Policies And Procedures (2018), https://umaine.edu/marketingandcommunications/home/policies-and-procedures/\#news [https://perma.cc/B9LD-ETJ8].

279. Two federal circuits have put faculty speech into a more-protected category, holding that the doctrine of academic freedom relieves faculty of a strict application of the Supreme Court's Connick/Garcetti regimen. See Demers v. Austin, 746 F.3d 402, 406 (9th Cir. 2014) (holding that Garcetti does not apply to faculty speech on matters of scholarship and teaching in a professor's First Amendment retaliation case); Adams v. Trs. of Univ. of N.C.-Wilmington, 640 F.3d 550, 562 (4th Cir. 2011) (holding that statements made by professor in tenure application were protected speech and stating that "Garcetti would not apply in the academic context of a public university"). However, there is no broad consensus that faculty necessarily have greater First Amendment protection than non-teaching staff, and the Supreme Court has not directly spoken to the issue.

280. See, e.g., David French, A New Campus Survey Reveals Just How Students are 'Unlearning Liberty, 'NAT'L REV. (Mar. 13, 2018, 3:32 PM), https://www.nationalreview.com/2018/03/a-new-campussurvey-reveals-just-how-students-are-unlearning-liberty/ [https://perma.cc/6ZVQ-TREM] (discussing a survey on how college students viewed free speech in comparison to inclusivity); Kathleen Parker, Trigger Warnings, Colleges, and the 'Swaddled Generation', WASH. POST (May 19, 2015), https://www. 
of access to campus newsmakers has provoked backlash when enforcement appears provoked by adverse coverage of particular controversies. At the University of North Alabama, following unflattering news coverage about the departure of the Vice President for Student Affairs, administrators circulated a "reminder" to employees of a policy that "requires all media inquiries be sent through [the university marketing] office so the proper administrators can examine the faculty and staff members' responses before releasing them to the media." 281 The circulation of the "reminder," followed shortly afterward by the firing of the student newspaper's longtime faculty adviser, provoked a censure from the College Media Association and widespread condemnation of the university. ${ }^{282}$ A private institution, Loyola University Chicago, sparked outcry by disseminating a policy requiring employees to forward media inquiries to the campus public-relations office, which would decide whether to approve the interview request. ${ }^{283}$ The policy was rescinded under pressure from journalists, faculty members, and free-speech organizations. $^{284}$

School districts and individual schools commonly instruct employees that they may not discuss work-related matters with journalists, or that interviews may be granted only with a district administrator's approval. In May 2019, when a Texas journalism teacher resigned her position in protest of heavy-handed censorship by school administrators, she told reporters that her teaching contract forbade her from saying anything to

washingtonpost.com/opinions/the-swaddled-generation/2015/05/19/162ea17a-fe6a-11e4-805c-c3f407e5a 9 e9_story.html?noredirect=on [https://perma.cc/GV67-9979] (discussing how it is not the job of universities to shield students from "triggering" topics they disagree with). In 2017, the University of California System launched the National Center for Free Speech and Civic Engagement in recognition of the need to grapple with tensions over freedom of expression and the friction that controversial speakers were creating at campuses across the country. See Emily Deruy, UC Launches New Free-Speech Center, MERCURY NewS (Oct. 26, 2017, 1:25 PM), https://www.mercurynews.com/2017/10/26/uc-launches-new-free-speech-center/ [https://perma.cc/EK3W-YJN2] (quoting University of California President Janet Napolitano: "Few issues today are more timely, or more challenging, than free speech on our nation's college campuses.").

281. Harley Duncan, Vice President Sends a Reminder to Employees of 'Media Protocol,' FLoR-ALA (Nov. 7, 2018), https://www.florala.net/news/vice-president-sends-a-reminder-to-employees-of-mediaprotocol/article_d7e1228c-e2d4-11e8-9658-2f178cc84909.html [https://perma.cc/YFC8-9DQ3].

282. Russ Corey, UNA Censured by Media Group, TimESDAILY (Nov. 28, 2018), https://www.tim esdaily.com/news/una-censured-by-media-group/article_4e69f4b0-4990-5add-afd7-2b0e61abd453.h tml [https://perma.cc/7YH6-5QC4].

283. Kate McGee, Loyola University Student Newspaper Blasts School's Restrictive Media Policy, WBEZ News (Feb. 13, 2019), https://www.wbez.org/shows/wbez-news/loyola-university-studentnewspaper-blasts-schools-restrictive-media-policy/bdd446bf-e53a-45c7-839b-069e46539c8b [https://perma.cc/CR5Y-NJPN].

284. Madison Savedra, Loyola Media Policy Altered, Under Review, Loy. PHX. (Feb. 27, 2019, 12:52 AM), http://loyolaphoenix.com/2019/02/loyola-media-policy-altered-under-review/ [https://perma.cc/6NF D-52DV]. 
the media. ${ }^{285}$ The Washington Post reported being unable to interview a New Jersey schoolteacher about her lawsuit alleging that she was made the fall guy for her supervisors' decision to censor the yearbook, because "[t]he district's media policy bans teachers from talking to reporters without the superintendent's consent." 286 The district's published policy states, in pertinent part: "All inquiries from members of the press will be referred to the Superintendent for response. A staff member who is requested to give an interview to a member of the press shall so inform the Superintendent, who may request to be present at the interview."287 Comparably restrictive media policies are publicly available in schools from Pennsylvania ${ }^{288}$ to Kansas ${ }^{289}$ to Washington. ${ }^{290}$ A reporter for the Fresno Bee, who authored an acclaimed series of articles about her local district's resistance to providing sex education even as teen pregnancy in the district spiked, told the Columbia Journalism Review that, even though California has a unique statute entitling journalists to come onto school property for newsgathering, her access to interview subjects is tightly controlled:

There is a law about access, but that's not the world I live in .... If I come into any front office at any school and identify myself, they're not going to let me in without calling the district. If I call a math teacher about some cool new program, they will refer to me to the communications team. They allow me great access, but I have to go to

285. Cory Dawson, Award-Winning Media Adviser Resigns After Censorship, Conflict with School Principal, STUDENT PRESS L. CTR. (May 15, 2019), https://splc.org/2019/05/award-winning-media-adviserresigns-after-censorship-conflict-with-school-principal/ [https://perma.cc/KQJ4-8SL8].

286. Marisa Iati, Teacher Accused of Censoring a MAGA T-Shirt Says She's a Trump Voter Who Just Followed Orders, WASH. POST (May 7, 2019), https://www.washingtonpost.com/education/2019/05/07/tea cher-accused-censoring-maga-t-shirt-says-shes-trump-voter-who-just-followed-orders/ [https://perma.cc/F4 PH-KRMR].

287. Wall TwP. Bd. Of Educ., District Regulation § 9120(C)(4): Public Information Program (Sept. 2009), https://www.straussesmay.com/seportal/Public/DistrictRegulation.aspx?Reg ulationid=9120\&id=c225768111b1489aa024ba0abfc4a200 [https://perma.cc/G3AG-G4VD].

288. See AvONworth SCH. DisT., MEDIA Protocol FOR VISITS, http://www.avonworth.k12.pa.us/M ediaProtocolforVisits.aspx [https://perma.cc/H95N-GHWT] ("All interview requests must go through the Director of Communications and Public Relations.").

289. See Hutchinson Pub. SCH., K: General Public Relations (Nov. 11, 2013), https://www.usd308.com/node/144\#KBC\%20Media\%20Relations [https://perma.cc/9LJ2-SANE] ("News and information concerning school events and programs may be released to the media with the approval of the superintendent.").

290. See Monroe Sch. Dist., StafF Hub, Media Best Practices, https://www.monroe.wednet.edu/ staff-hub/departments/communications/media-best-practices [https://perma.cc/3H4Q-ZF59]. The policy instructs employees of a Washington school district to "refer all media inquiries to the Public Information Officer" and reinforces it with a reminder: "Please do not contact reporters directly. The Communications Department is the only district department authorized to distribute media advisories, news releases or requests for media coverage." Id. 
them to get that access. ${ }^{291}$

\section{E. Gag Policies in Local Government}

City and county agencies, too, commonly restrain employee speech in ways irreconcilable with the NTEU standard. The Pittsburgh Post-Gazette was forced to rely on unnamed sources in describing a 2016 spate of attacks on jail guards by inmates, because employees of the Pittsburgh jail system are not allowed to speak to the media. ${ }^{292}$ After winning election as mayor of Little Rock, Arkansas, in 2018, Frank Scott Jr. instructed all city department heads to route all calls from the news media to his office, a practice that the mayor's communications director called "standard in medium to large-sized cities." 293

Published examples of restrictive employee-speech regulations are readily accessible online, enacted by local governments of all sizes and levels of sophistication. A "Communications Policy" disseminated by the City of Surprise, Arizona, a suburb of Phoenix, instructs city employees that they must inform their department head and the city's communications director of any media contacts, and must never offer "personal views" to the media. ${ }^{294}$ City employees in the Dallas suburb of Allen, Texas, are told to "direct media inquiries of any type to his/her department director or designated representative," and even department heads are told that they must consult city supervisors or legal counsel before addressing "controversial" issues or a range of other subjects deemed sensitive, including injuries to city employees, personnel problems, or interruptions in city services. ${ }^{295}$ Another Texas municipality, the City of Kerrville, tells its employees:

An employee contacted by a media representative inquiring about a topic

291. Tony Biasotti, Fresno Bee Endures Outrage to Tell Important Stories About Sex Education, COLUM. JOURNALISM Rev. (Nov. 30, 2017), https://www.cjr.org/united_states_project/fresno-beesex-ed-teen-pregnancy.php [https://perma.cc/9PYW-3GAG]

292. Rich Lord \& Kate Giammarise, Guards Union at Allegheny County Jail Concerned Over Assaults, PITT. POST-GAZETTE (May 4, 2016, 11:20 PM), https://www.post-gazette.com/local/city/2016/05/05/Alleg heny-County-Jail-guards-union-expresses-concern-over-assaults/stories/201605050024 [https://perma.cc/Z 7HZ-CA2R].

293. Rachel Herzog, Media Queries Routed to Little Rock Mayor's Office, ARK. DEMOCRATGAZETTE (Mar. 23, 2019, 4:30 AM), https://www.arkansasonline.com/news/2019/mar/23/media-quer ies-routed-to-lr-mayor-s-offi/ [https://perma.cc/DR6J-SUE8].

294. City OF SURPRISE, ARIZ., COMMUNICATIONS POLICY 6 (Apr. 2005), https://www.surpriseaz.gov/ DocumentCenter/View/4410/CommunicationsPolicy [https://perma.cc/G2BH-NFY9].

295. City of Allen, TeX., Administrative Directive \& Policy Manual § III(5), (2) (Mar. 28, 2003), https://www.cityofallen.org/DocumentCenter/View/2844/City-of-Allen-Policy-Manual?bidId= [http s://perma.cc/4ZHW-33GC]. 
must forward the representative to the Public Information Office, provide notice of the contact, and any relevant background information. If a decision is made for an employee to answer a representative's questions in person, over the telephone, and/or live, the Public Information Office must be involved to assist. ${ }^{296}$

In Idaho Falls, a city media-relations policy directs employees to "immediately" refer media inquiries to a supervisor, who then must notify the public-information office-and then reiterates that the requirement especially applies to "sensitive" or "controversial" media inquiries. ${ }^{297}$

In sum, regulations on the books at all levels of government forbid public employees from discussing their work with the press and public, without regard to the weight of First Amendment precedent finding such policies unconstitutional.

\section{CHALLENGING GAG ORDERS}

\section{A. Employee Challenges are Infrequent and Unlikely}

A public employee typically gives no thought in the abstract to the "injury" of being constrained from unfettered contact with the news media. The interest in speaking with a journalist arises either when the employee perceives a problem and reaches out for help engaging with a larger public audience, or when the journalist makes the first approach seeking information. In neither scenario is there likely to be much advance notice, nor is there likely to be the time to obtain counsel and bring a challenge while the information is still current and newsworthy.

To the extent that an employee will ever be motivated to initiate a challenge, it will inevitably be after experiencing adverse employment action - which presents its own obstacles. A jobless employee may be unable to hire counsel. An employee who immediately finds satisfactory substitute employment will lack motivation to litigate against the former workplace. And the employee may not be given a full and truthful explanation for the adverse action that connects back to the contact with news media.

Moreover, it is rare that the mere act of speaking to a journalist without

296. City of Kerrville, TeX., Personnel Policies \& Procedures Manual $\$ 2.03$ (B) (Jan. 1, 2019), https://www.kerrvilletx.gov/DocumentCenter/View/24646/01_Personnel-Policy-Manual---Eff ective-010119?bidId= [https://perma.cc/K4ZG-24DA].

297. City of IDAho Falls, IDAho, MEdia Relations Policy $\S \S$ IV-V (Dec. 14, 2017), https:// www.idahofallsidaho.gov/DocumentCenter/View/6097/Media-Relations-Policy [https://perma.cc/K WL8-V83X]. 
approval will itself be the motivating factor for an employee's dismissal. It is far more likely that the employer will be aggrieved by the content of the speech and not the fact of the conversation, and that the punishment will be based on having disparaged the employer, contradicted the employer's desired message, or leaked nonpublic information. ${ }^{298}$ Consequently, cases will more probably be tried by applying the Pickering line of caselaw to the speaker's words, rather than as facial challenges to the gag policy. This points to the importance, from an employee-rights perspective, of facially challenging policies suspected to be unconstitutionally restrictive before they are enforced, so that the more protective NTEU standard rather than the Pickering balancing standard will apply.

\section{B. A Roadmap for Third-Party Challenges: Judicial Gag Orders on Trial Participants}

Where a speaker wishes to share information, First Amendment protections apply to both the speaker and the intended recipient of the speech. ${ }^{299}$ In other words, freedom of speech "necessarily protects the right to receive." 300 This right to receive information is a separate, independent corollary of the First Amendment speech and press freedoms. An "informed citizenry" is "vital to the functioning of a democratic society," 301 and thus, "the First Amendment protects the news agencies right to receive protected speech." 302 Indeed, "without some protection for seeking out the news, freedom of the press could be eviscerated." 303

While there is no indication that news organizations have litigated

298. The case of a fired Texas school secretary, Salge v. Edna Independent School District, provides a typical scenario. 411 F.3d 178 (5th Cir. 2005). In Salge, the employee lost her job after telling a newspaper reporter, in response to a question, that the principal would not be receiving a new contract. Id. at 181-83. Although the employee's firing was based in part on violation of a classic employee-gag rule - a prohibition against "contacting the media about school district news" - the district also cited a second basis, compromising the confidentiality of personnel information, which did not directly implicate the gag rule. Id. at 185 . Whatever its basis, the Fifth Circuit found the firing unlawful under a Pickering analysis and upheld the judgment in the employee's favor. Id. at 197. As this case exemplifies, it is rare to find a factually "clean" case in which no basis other than unauthorized contact with the news media is the rationale for an adverse personnel action.

299. See Va. State Bd. of Pharmacy v. Va. Citizens Consumer Council, Inc., 425 U.S. 748, 756 (1976) ("[T] he protection afforded [by the First Amendment] is to the communication, to its source and to its recipients both.").

300. Kleindienst v. Mandel, 408 U.S. 753, 762-63 (1972) (citations omitted).

301. NLRB v. Robbins Tire \& Rubber Co., 437 U.S. 214, 242 (1978).

302. Davis v. E. Baton Rouge Par. Sch. Bd., 78 F.3d 920, 926 (5th Cir. 1996) (citing Va. State Bd. of Pharmacy, 425 U.S. at 756-57).

303. Branzburg v. Hayes, 408 U.S. 665, 681 (1972). 
First Amendment challenges to controls on public employee speech, there are parallels in the oft-litigated context of gag orders on trial participants. ${ }^{304}$ In those cases, journalists have had little difficulty establishing standing to challenge the breadth of judicial orders banning attorneys, parties, and witnesses from speaking with the media. ${ }^{305}$ Journalists consequently should have standing to litigate the constitutionality of employee gag policies in the absence of a motivated employee plaintiff.

Standing has both constitutional and prudential dimensions. ${ }^{306} \mathrm{~A}$ litigant presents no constitutionally justiciable question if there is no "case or controversy" for the judiciary to redress. ${ }^{307}$ At times, courts have permitted litigants to proceed in a representational capacity on behalf of others who are more directly injured but are unable, for practical reasons, to assert their own interests, ${ }^{308}$ such as abortion doctors standing in the place of future prospective patients who will not know that they need abortion services until the matter is too time-urgent to be litigated. ${ }^{309}$

Establishing the existence of a justiciable question requires an injury to a legally cognizable interest, a causal connection fairly traceable to the wrong that is the subject of the suit, and a substantial likelihood that the injury is redressable by an available remedy. ${ }^{310}$ Prudential standing presents a more direct impediment to a journalist asserting a right to challenge a restraint on the speech of potential news sources, as the doctrine is recognized as presenting a "general prohibition on a litigant's raising another person's legal rights." 311 To challenge a governmental restraint on access to news sources, a journalist plaintiff must satisfy both

304. See United States v. Brown, 218 F.3d 415, 431 (5th Cir. 2000) (holding that gag orders may be imposed on trial participants if a substantial threat to a fair trial exists); Gentile v. State Bar of Nev., 501 U.S. 1030, 1058 (1991) (holding that an attorney's extrajudicial statements to the media were not "substantially likely to cause material prejudice").

305. See, e.g., In re Dow Jones \& Co., 842 F.2d 603, 608 (2d Cir. 1988); Davis v. E. Baton Rouge, 78 F.3d at 927.

306. Mangual v. Rotger-Sabat, 317 F.3d 45, 56 (1st Cir. 2003).

307. See Marc Rohr, Fighting for the Rights of Others: The Troubled Law of Third-Party Standing and Mootness in the Federal Courts, 35 U. MIAMI L. REV. 393, 394 (1981) (explaining that the only constitutional imperative to qualify for standing is that the party suffer a personal "injury in fact" traceable to the challenged practice).

308. See Tacy F. Flint, Comment, A New Brand of Representational Standing, 70 U. CHI. L. REV. 1037, 1045-52 (2003) (explaining how courts have allowed both "representational" standing on the part of associations whose members individually would have standing, as well as "third party" standing in cases where the directly injured party faces hindrances making litigation impracticable).

309. Planned Parenthood v. Danforth, 428 U.S. 52, 57 (1976).

310. Steel Co. v. Citizens for a Better Env’t, 523 U.S. 83, 103 (1998); Lujan v. Defs. of Wildlife, 504 U.S. 555, 560-61 (1992).

311. Allen v. Wright, 468 U.S. 737, 751 (1984). 
aspects of the standing doctrine.

Because a restraint on speech poses such a danger of inhibiting speakers into silencing themselves, federal courts have liberally entertained facial challenges brought under the First Amendment. ${ }^{312}$ Thus, a plaintiff may challenge a restriction on speech as substantially overbroad even if the restriction has some constitutionally permissible applications. ${ }^{313}$

In Nebraska Press Association v. Stuart, a Nebraska state trial judge "entered an order restraining the [news media] from publishing or broadcasting accounts of confessions or admissions ... or facts 'strongly implicative" of the defendant. ${ }^{314}$ The Court found that the order was an unconstitutional prior restraint in contravention of the principles recognized in Near $v$. Minnesota. ${ }^{315}$ Acknowledging the potential prejudicial impact of publicity on a defendant's constitutional right to a fair trial, the justices suggested that less restrictive curative measures would be permissible. ${ }^{316}$ Nebraska Press built on decades of First Amendment precedent invalidating contempt sanctions imposed on journalists who published editorials critical of the conduct of pending trials or misleading coverage that judges considered prejudicial to ongoing trials. $^{317}$

Unable to restrain journalists from publishing lawfully gathered information about criminal trials, lower courts more commonly have attempted instead to restrain parties and their counsel from talking publicly about their cases, insisting that silence is necessary to avoid prejudicing prospective jurors. ${ }^{318}$ As in the Nebraska Press case, these restraints-byproxy on journalists' coverage of legal proceedings have proven difficult to justify. ${ }^{319}$

312. See Thornhill v. Alabama, 310 U.S. 88, 97 (1940) ("Proof of an abuse of power in the particular case has never been deemed a requisite for attack on the constitutionality of a statute purporting to license the dissemination of ideas.").

313. Russell H. Falconer, Note, Institutional Rights, Individual Litigants: Standing to Sue Under the Press Clause, 87 TeX. L. Rev. 1223, 1237-38 (2009).

314. 427 U.S. 539, 541 (1976).

315. Id. at 570; Near v. Minnesota, 283 U.S. 697, 713 (1931).

316. Neb. Press Ass' $n, 427$ U.S. at 565.

317. See Bridges v. California, 314 U.S. 252, 278 (1941); Craig v. Harney, 331 U.S. 367, 375-77 (1947).

318. Neb. Press Ass'n, 427 U.S. at 551-54.

319. While this discussion focuses on the ability of journalists to vindicate their interests in access to information, trial participants can of course assert their own more clearly protected free-speech rights, and have done so successfully when judicially gagged. See, e.g., Chase v. Robson, 435 F.2d 1059, 1060, 1062 (7th Cir. 1970) (granting petition of Vietnam War protesters, facing trial on charges of ransacking a federal draft office, to vacate their trial judge's order forbidding the parties or their counsel from making any public statement about the case). 
Although the would-be speaker faces the greatest personal jeopardy from a judicial gag order, courts have consistently found that journalists have a sufficiently concrete interest in access to lawyers, parties and witnesses to establish standing - whether the injury is conceived as one directly to the journalist or as derivative of the injury to the trial participant who is at risk of contempt sanctions.

For instance, when a federal district judge in Ohio gagged all participants in a series of wrongful death lawsuits arising out of the shooting of anti-war demonstrators at Kent State University, the Sixth Circuit found that the CBS television network had standing to challenge the ban:

We are not persuaded by the argument that petitioner lacks standing because it is not a party to the civil litigation. The fact remains that its ability to gather the news concerning the trial is directly impaired or curtailed. The protected right to publish the news would be of little value in the absence of sources from which to obtain it. ${ }^{320}$

The appeals court found that the prohibition - which applied not just to direct participants, but even extended to "relatives, close friends, and associates"-was an unconstitutional prior restraint threatening freedom of the press. ${ }^{321}$

Similarly, the Tenth Circuit found standing for news organizations to challenge a district judge's order directing jurors not to grant interviews after their service in a high-profile civil rights lawsuit against police officers accused of framing an innocent man for murder. ${ }^{322}$ Although the Albuquerque Journal was not party to the underlying litigation, the judges found that the newspaper had standing to intervene "because the court's order impeded its ability to gather news, and that impediment is within the zone of interest sought to be protected by the First Amendment." 323 Other circuits - even those that ultimately have found gag orders justifiablehave similarly found that journalists have a cognizable injury when denied access to trial participants who are silenced by court order. ${ }^{324}$

A practical rationale for entertaining First Amendment claims from

\footnotetext{
320. CBS, Inc. v. Young, 522 F.2d 234, 237-38 (6th Cir. 1975).

321. Id. at 236, 239-41.

322. Journal Publ'g Co. v. Mechem, 801 F.2d 1233, 1235 (10th Cir. 1986).

323. Id.

324. See, e.g., Radio \& Television News Ass'n v. U.S. Dist. Ct. for Cent. Dist. of Cal., 781 F.2d 1443, 1445-48 (9th Cir. 1986) (finding sufficient injury to news media to confer standing to challenge order restraining criminal trial participants from making any statements about the merits of the case to the media, but finding only "very limited incidental" effect on constitutionally protected rights and upholding silencing order as reasonable).
} 
journalists is that trial participants themselves will have little incentive to mount their own challenges. A witness or juror will not have enough of a stake in giving an interview to be motivated to get counsel and sue, and even though a party or a party's counsel might have greater incentive, direct participants will be unlikely to risk the trial judge's wrath by facially challenging a gag order. ${ }^{325}$

Gag orders on trial participants are often analyzed as prior restraintsand thus subject to the heavy presumption of unconstitutionality-even when the challenger is a news organization that is not directly prevented from speaking. ${ }^{326}$ This was the approach taken by the court in the Kent State shooting case, ${ }^{327}$ and by subsequent courts following the Sixth Circuit's lead. ${ }^{328}$ When a gag order is regarded as a prior restraint on publishing, it will be presumed unconstitutional unless there is a "clear showing" that the restriction is necessary to prevent a "serious and imminent threat" to a fair trial. ${ }^{329}$

Some reviewing courts, however, distinguish between a direct and indirect restraint on the ability to disseminate news, finding that a gag on trial participants deprives journalists of no constitutionally protected right because there is no constitutional entitlement to interview any particular source. ${ }^{330}$ Those courts consequently relax their scrutiny when gag orders are challenged by media intervenors rather than by trial participants themselves. ${ }^{331}$ This line of reasoning has been influenced by the Supreme Court's observation in Nebraska Press that orders limiting what lawyers and witnesses may say to anyone outside of the proceedings are "measures short of prior restraints on publication" and therefore more constitutionally tolerable than a direct restraint. ${ }^{332}$

325. Sheryl A. Bjork, Comment, Indirect Gag Orders and the Doctrine of Prior Restraint, 44 U. MiAmi L. REV. 165, 187 (1989) (noting that prosecutors and defendants are reluctant to oppose gag orders for fear of prejudicing the presiding judge against them).

326. See Rene L. Todd, Note, A Prior Restraint by Any Other Name: The Judicial Response to Media Challenges of Gag Orders Directed at Trial Participants, 88 Mich. L. Rev. 1171, 1174 (1990) (stating that most courts examine participant-directed gag orders using "traditional prior restraint analysis”); see also Conn. Magazine v. Moraghan, 676 F. Supp. 38, 42 (D. Conn. 1987) (“An order prohibiting extrajudicial comments by counsel constitutes a prior restraint on the right to gather news and derivatively on publication.") (citing Journal Publ'g Co., 801 F.2d at 1236).

327. CBS, Inc. v. Young, 522 F.2d 234, 238-39 (6th Cir. 1975).

328. See, e.g., People v. Sledge, 879 N.W.2d 884, 892-93 (Mich. Ct. App. 2015) (following CBS, Inc., and declaring judicial gag order to be an unconstitutional prior restraint on media intervenors).

329. United States v. Ford, 830 F.2d 596, 599-601 (6th Cir. 1987).

330. See, e.g., Radio \& Television News Ass'n v. U.S. Dist. Ct. for Cent. Dist. of Cal., 781 F.2d 1443, 1447 (9th Cir. 1986).

331. See, e.g., id. (requiring only a reasonable justification for a judge's gag order on participants in criminal trial).

332. Neb. Press Ass'n v. Stuart, 427 U.S. 539, 563-65 (1976). See, e.g., State ex rel. The 
Illustratively, the Second Circuit took this view in a 1988 case challenging a trial judge's order gagging all of the participants in a federal racketeering trial in which a former New York congressman was among the high-profile defendants. ${ }^{333}$ In that case, In re Application of Dow Jones $\& C o$., the court found that news organizations had standing to challenge the order because they were the prospective recipients of speech, but declined to characterize the order as a "prior restraint" on the media plaintiffs. ${ }^{334}$ "[W] e conclude that there is a fundamental difference between a gag order challenged by the individual gagged and one challenged by a third party; an order objected to by the former is properly characterized as a prior restraint, one opposed solely by the latter is not," the judges wrote. ${ }^{335}$ The court looked to the relative perils faced by the actors in the case, noting that only the speakers, not the journalists, risked contempt sanctions if the court's order was violated. ${ }^{336}$ Because the order did not qualify as a prior restraint, it was not treated as presumptively unconstitutional; rather, the court upheld its legality under a balancing-of-interests approach, finding that the proper standard is "whether there is a reasonable likelihood that pretrial publicity will prejudice a fair trial." 337

By analogy, if restrictions on employees' speech are viewed as directly injuring the news organizations that seek to interview them, the level of scrutiny afforded to the prohibition will be more rigorous and the prohibition will be less likely to survive if the challenge is brought by journalists. In an instructive case, a federal district court in Louisiana took the position that a judicial gag on trial participants would be analyzed under the rigorous prior-restraint doctrine only if challenged by the party actually restrained from speaking, not by a news organization on which the restraint falls less directly. ${ }^{338}$

Missoulian v. Mont. Twenty-First Judicial Dist. Ct., 933 P.2d 829, 839 (Mont. 1997) (applying Nebraska Press and concluding: "While an order restraining the trial participants from communicating with the press may be a prior restraint upon the participants as communicators, it is not a prior restraint upon the press."). A well-reasoned critique for the Miami Law Review argues that the Sixth Circuit has the better argument, because the Supreme Court's prior-restraint jurisprudence is best understood as protecting not just speakers but speech, and a judicially-imposed gag order on speaking to the media is a de facto prohibition on the dissemination of information by journalists. Bjork, supra note 325 , at $183-85$.

333. In re Application of Dow Jones \& Co., 842 F.2d 603, 604-05 (2d Cir. 1988).

334. Id. at 607-09. The court relied in part on the Ninth Circuit's resolution in Radio \& Television News Ass' $n, 781$ F.2d at 1446 (holding that a restraining order not directed at the press does not restrain press First Amendment rights).

335. In re Application of Dow Jones \& Co., 842 F.2d at 609 .

336. Id. at 608 .

337. Id. at 610 (quotation marks omitted).

338. See United States v. Davis, 902 F. Supp. 98, 102 (E.D. La. 1995) ("The First Amendment interests of trial participants in their own speech are simply not doctrinally coextensive with the 
The diminished level of First Amendment protection that applies to public employees does not extend to journalists. When the government restrains journalists from publishing, the government cannot fall back on the "efficiency" justifications that legitimize restricting employee speech. Consequently, if a restriction on public employee speech is seen as directly restraining journalistic speech, it should be presumed unconstitutional absent the most compelling of justifications.

Conversely, if the gag order is seen as an injury only to the public employee, the journalist may be reduced to piggybacking on the employee's more limited set of rights. In the somewhat analogous setting of access to interviews with prison inmates, the Supreme Court held in Pell v. Procunier that the California prison system's policy of limiting prisoners' ability to grant interviews was justified by reasonable safety concerns and did not violate the rights of either inmates or the journalists who sought to interview them. ${ }^{339}$ The Court explained:

It is one thing to say that a journalist is free to seek out sources of information not available to members of the general public, that he is entitled to some constitutional protection of the confidentiality of such sources ... and that government cannot restrain the publication of news emanating from such sources.... It is quite another thing to suggest that the Constitution imposes upon government the affirmative duty to make available to journalists sources of information not available to members of the public generally. That proposition finds no support in the words of the Constitution or in any decision of this Court. ${ }^{340}$

The takeaway from Pell is that journalists may have only the benefit of the First Amendment protection afforded to their sources (which, in Pell, turned out to be none). ${ }^{341}$ In the case of restrictions on interviews with public employees, a court analogizing to Pell might afford journalists only the quantum of rights that their would-be sources would enjoy under Garcetti. As with the inmates in Pell, journalists do not have a constitutionally protected right to insist on interviewing any particular government employee. ${ }^{342}$

\footnotetext{
interests of news agencies in that speech.").

339. 417 U.S. 817, 819-20, 831-35 (1974).

340. Id. at $834-35$ (citations omitted).

341. Id. at 834 .

342. The Ninth Circuit, upholding a judicially imposed gag on trial participants in Radio \& Television News Association, made the same observation that journalists do not have a First Amendment right to insist on access to interview particular attorneys of their choosing. See Radio \& Television News Ass'n v. U.S. Dist. Ct. for Cent. Dist. of Cal., 781 F.2d 1443, 1447 (9th Cir. 1986) ("[T]he media's collateral interest in interviewing trial participants is outside the scope of protection offered by the first amendment.... The media's desire to obtain access to certain sources of
} 
While somewhat logically analogous, the Pell prison setting is distinguishable. The Pell Court emphasized that journalists had effective alternative means of keeping watch on prison conditions other than by arranging interviews, including by visiting the prisons and questioning any inmates they encountered. ${ }^{343}$ The policy upheld in Pell was thus a more limited gag order than the ones typically in force in the public workplace. Moreover, the overriding safety considerations that were found to justify restrictions on First Amendment freedoms in Pell are not nearly so pronounced outside of prisons and jails.

These two analogous bodies of law-the first involving trial participants and the second involving prison inmates - point in somewhat different directions, leaving uncertainty about the standard that applies if a media plaintiff challenges a gag order on public employees. Nevertheless, in neither context have journalists failed to surmount the threshold standing requirements to initiate a case.

Strong practical considerations counsel in favor of recognizing standing for journalists to challenge employer policies that restrain employees from speaking to the media, whether in their own right or as stand-ins for the employees themselves. The Supreme Court has recognized that the case for third-party standing is especially compelling when the fear of harm from adverse publicity deters the most directly injured party from suing. ${ }^{344}$ This would apply most especially in the case of employees who-but-for the threat of punishment if discovered by their employers-would supply information to journalists anonymously as whistleblowers. Employees are highly unlikely to be so motivated to speak to the media as to invest money and risk workplace relationships - exposing themselves as would-be whistleblowers - to initiate First Amendment litigation adversarial to their own employers. This "motivation" consideration has been recognized as a justification for conferring standing on news organizations in the context of gags on trial participants. ${ }^{345}$ Moreover, an employee may lose incentive to pursue a case in midstream, either because the matter on which the

information, that otherwise might be available, is not a sufficient interest to establish an infringement of freedom of the press in this case." (citation omitted)).

343. Pell, 417 U.S. at 830.

344. See Carey v. Population Servs. Int'1, 431 U.S. 678, 681-84, 684 n.4 (1977) (plurality opinion) (citing Singleton v. Wulff, 428 U.S. 106, 117 (1976)) (recognizing that minors would not come forward to challenge a law forbidding them from purchasing contraceptives, because doing so would expose their private sexual practices, thus making a contraceptive vendor a suitable stand-in plaintiff).

345. Todd, supra note 326, at 1192 ("Witnesses, for example, may have little at stake in the primary litigation at issue, and thus may have little motivation to spend time and effort challenging a restraint on their speech regarding that litigation. Likewise, litigants, who bear the cost of the primary litigation, may be unable to spare the resources necessary to challenge participant-directed gag orders."). 
employee wished to be heard becomes stale, or because the employee changes jobs. A news organization is likely to confront the same gag policy over and over again, while an employee might encounter it only once in a career.

For all of these reasons, news organizations are suitable plaintiffs well-incentivized to effectively litigate the issues involved in workplace gag orders. ${ }^{346}$ Whether the impact of employer gag policies is viewed as a prior restraint on journalists' ability to publish, or whether the First Amendment interest is located elsewhere-perhaps in the right to receive information, ${ }^{347}$ or derivatively, in the constitutional interests of the speaker - news organizations should have no difficulty establishing that they satisfy the threshold constitutional and prudential standing requirements to pursue a challenge. Even a membership organization that represents the interest of the news media, such as the Society of Professional Journalists, may have standing to initiate litigation challenging workplace gag policies. ${ }^{348}$

The policy considerations that favor a skeptical view of judicially imposed gag orders apply even more forcefully in the employment setting. While a trial judge rarely will have a self-serving reason for silencing trial participants - the judge's rationale is almost always to guard against prejudicial pretrial publicity - an agency restraining its employees from speaking to the media has obvious, self-interested motives. And while the right to a fair trial is an interest of constitutional dimension (at least in the criminal setting) so that there are constitutional imperatives on both sides of the equation, no such offsetting constitutional concern militates in favor of agencies silencing their employees. For all of these reasons, restraints on public-employee speech should receive review at least as rigorous as

346. When permitting a party to litigate the injuries of others, federal courts inquire as a threshold matter whether the litigant's interest is sufficiently concrete to provide motivation to litigate the case. See Singleton, 428 U.S. at 114 ("The courts depend on effective advocacy, and therefore should prefer to construe legal rights only when the most effective advocates of those rights are before them.").

347. While not as well-defined as the right to publish information, the right to receive information has been acknowledged in multiple Supreme Court decisions spanning the past half-century. See Stanley v. Georgia, 394 U.S. 557, 564, 568 (1969) (recognizing "right to receive information and ideas" in striking down statute that criminalized private possession of obscene materials); Va. State Bd. of Pharmacy v. Va. Citizens Consumer Council, Inc., 425 U.S. 748, 756 (1976) (where there is a willing speaker, "the protection afforded is to the communication, to its source and to its recipients both").

348. The Utah Supreme Court recognized SPJ as a proper party to bring a First Amendment-based challenge to the closure of a judicial hearing on the grounds that the SPJ's individual journalist members would themselves have standing and that the relief sought—opening the hearing - did not require the participation of the members as individuals. Soc'y of Prof'l Journalists v. Bullock, 743 P.2d 1166, 1175 (Utah 1987). 
that regularly applied to invalidate overbroad trial-court gag orders. ${ }^{349}$

\section{CONCLUSION}

America is facing a crisis in the accessibility of civically essential information. The number of working professional journalists is dwindling to lows unprecedented in modern history, and many small communities are no longer served by a local newspaper at all. ${ }^{350}$ In an apocalyptic column for the Washington Post, acclaimed journalists Douglas McLennan and Jack Miles gave voice to the worst fears of those who rely on the fraying information safety net that traditional news organizations provide: "[O]nce newspapers stop reporting any facts at all, nothing will stop autonomous spin - spin that generates its own facts, such as the 'fact' that Barack Obama is a foreign-born closet Muslim-from taking over entirely. The loyal opposition will no longer be there to research, factcheck, report and oppose." ${ }^{351}$

At the same time that newsrooms have been hollowed out by layoffs, or closed or merged out of existence entirely, government investment in pushing out its own message through public-relations professionals has never been greater. The U.S. government is conservatively estimated to spend $\$ 1.5$ billion a year on public relations, according to the Government Accountability Office. ${ }^{352}$ States and their subsidiary agencies are similarly

349. One offsetting consideration that may make the case against gag orders less compelling outside of the judicial setting is that there is a recognized First Amendment right for journalists to attend trials and all other critical stages of judicial proceedings. Richmond Newspapers v. Virginia, 448 U.S. 555, 580-81 (1980). There is no equivalent First Amendment right of access to information about the workings of executive or legislative entities. See McBurney v. Young, 569 U.S. 221, 232, 237 (2013) (declining to recognize a right of constitutional dimension entitling requesters to obtain public records from state executive-branch agencies).

350. See Erin Keane, The U.S. Newspaper Crisis is Growing: More Than 1 in 5 Local Papers Have Closed Since 2004, SALON (Oct. 16, 2018, 6:20 PM), https://www.salon.com/2018/10/16/the-u-snewspaper-crisis-is-growing-more-than-1-in-5-local-papers-have-closed-since-2004/ [https://perma.cc/Y5 MR-7KNQ] (documenting the growing phenomenon of "news deserts" resulting from the shutdown of some 1,800 newspapers since 2004); Sasha Lekach, Fewer Than Half of Newspaper Jobs from 15 Years Ago Still Exist, MASHABLE (Apr. 4, 2017), https://mashable.com/2017/04/04/newspaper-publishers-jobs-declinebls/\#X1GBk_w84sq8 [https://perma.cc/FA4U-QVCW] (quoting Bureau of Labor Statistics report that shows, over the past fifteen years, more than half the jobs in the American news industry have disappeared); Dermot Murphy, When Local Papers Close, Costs Rise for Local Governments, COLUM. JouRnALISM REV. (June 27, 2018), https://www.cjr.org/united_states_project/public-finance-local-news.php [https://perma.cc /6QKD-5AAZ] (reporting that "local newspaper circulation numbers dropped by roughly [thirty] percent" during the preceding fifteen years, and citing academic studies suggesting that "a lack of local media coverage is associated with less informed voters, lower voter turnouts, and less engaged local politicians").

351. Douglas McLennan \& Jack Miles, A Once Unimaginable Scenario: No More Newspapers, WASH. PosT (Mar. 21, 2018, 1:16 PM), https://www.washingtonpost.com/news/theworldpost/wp/2018/03/21/ne wspapers/ [https://perma.cc/6NLE-23E2].

352. U.S. Gov'T ACCOUntability OfFice, GAO-17-711, Public Relations Spending: 
staffing up their "storytelling" capability, to put their version of what the government is doing directly before audiences, bypassing traditional journalistic gatekeepers who might fact-check their accounts. ${ }^{353}$

As the diverging trajectories of these two trend lines makes clear, it is harder than ever for news organizations to get past the "spin" offered by public-relations professionals to inform the public about what is really going on inside government agencies - and there are more professional operatives than ever whose job is to shape public opinion to create a favorable impression of the agency. ${ }^{354}$ In such a climate, journalists need ready access to the insiders who can provide a candid, unfiltered look at how government is working and where it is falling short. As a longtime Washington, D.C., reporter told the Poynter Institute's journalism blog: "I don't think there is any question about it. When you talk with people who are under the oversight of a PIO, you get a massively different story than when you are free to talk to a source without that supervision." 355 Gagging employees from speaking to the media manifestly disserves the public's interest in honest, accountable government. As one commentator wrote in assessing the impact of the Garcetti ruling on the job security of journalists' sources: "If government employees can be disciplined without First Amendment limits for job-related speech, government employers now have another tool to discourage, intimidate and punish whistleblowers

SElected Agencies' Activities Supported by Contracts and Public AfFairs Staff (2017), https://www.gao.gov/assets/690/687089.pdf [https://perma.cc/AVK4-ADT5]; see also id. at 7 (reporting that, not counting expenses on in-house employees, contracts with outside vendors for public relations and advertising services accounted for almost $\$ 1$ billion of federal spending over fiscal years 2006 to 2015).

353. See, e.g., Craig Harris, No Spin: State Public-Relations Jobs, Cost Rise Sharply Under Gov. Doug Ducey, ARIZ. REPUBLIC (Jan. 22, 2018, 6:00 AM), https://www.azcentral.com/story/news/local /arizona-investigations/2018/01/22/no-spin-number-state-pr-jobs-jump-cost-increases-29-percentunder-gov-doug-ducey/1041831001/ [https://perma.cc/NP5D-MCSK] (reporting that the state of Arizona employed fifty-seven senior staff members dedicated to public relations, a twenty-four percent increase since 2014 at a time when other government functions were being cut); Adam Andrzejewski, Oregon State Government's \$278 Million Self-Promotion 'PR' Machine, FORBES (May 20, 2017, 7:00 AM), https://www.forbes.com/sites/adamandrzejewski/2017/05/20/oregon-stategovernments-278-million-self-promotion-pr-machine/\#414b78de23a9 [https://perma.cc/U4BB-LRN K] (reporting that, between 2012 and 2016, Oregon state agencies spent \$110 million to employ 303 people working in marketing, promotions and public relations, in addition to $\$ 168$ million paid to outside firms).

354. "At its core, public relations is about influencing, engaging and building a relationship with key stakeholders across a myriad of platforms in order to shape and frame the public perception of an organization." About Public Relations, PUB. REL. SOC'Y OF AM., https://www.prsa.org/all-about-pr/ [https://perma.cc/72QU-5M3M] (last visited Oct. 24, 2019). See also id. (describing the role of a public-relations professional to include "[p]rotecting the reputation of an organization").

355. Al Tompkins, SPJ Research Suggests that a Surge in PIOs Negatively Impacts Journalism, POYNTER (Sept. 5, 2018), https://www.poynter.org/newsletters/2018/spj-research-suggests-that-asurge-in-pios-negatively-impacts-journalism/ [https://perma.cc/FX8B-WSCU]. 
and leakers. ..."356 Concurring in a Fourth Circuit decision that protected the speech of a former police commander-Michael Andrew, terminated for leaking an internal memo to a newspaper reporter-Judge Harvie Wilkinson emphasized the special importance of protecting public employees' ability to furnish information to today's diminished press corps:

To throw out this citizen who took his concerns to the press on a motion to dismiss would have profound adverse effects on accountability in government. And those effects would be felt at a particularly parlous time. It is well known that the advent of the Internet and the economic downturn have caused traditional news organizations throughout the country to lose circulation and advertising revenue to an unforeseen extent.... [I]n these most difficult of times, not only investigative coverage, but substantive reports on matters of critical public policy are increasingly shortchanged. So, for many reasons and on many fronts, intense scrutiny of the inner workings of massive public bureaucracies charged with major public responsibilities is in deep trouble . . . .

[T]he First Amendment should never countenance the gamble that informed scrutiny of the workings of government will be left to wither on the vine. That scrutiny is impossible without some assistance from inside sources such as Michael Andrew. Indeed, it may be more important than ever that such sources carry the story to the reporter, because there are, sad to say, fewer shoeleather journalists to ferret the story out. ${ }^{357}$

In a December 2016 white paper issued by the American Association of University Professors, a coalition of free-expression organizations decried worsening impediments imposed by campus media-relations officials that inhibit campus journalists from gaining access to newsmakers:

No postsecondary institution should require its faculty or staff to clear interactions with the student media through an institutional publicrelations office, nor should campus public-relations offices obstruct student journalists from gaining direct access to those in positions of official authority. The community is entitled to hear directly from campus officials about how they perform their jobs and wield their authority - through face-to-face interaction with journalists, not simply prepared statements. ${ }^{358}$

356. Drechsel, supra note 159 , at 139.

357. Andrew v. Clark, 561 F.3d 261, 272-73 (4th Cir. 2009) (Wilkinson, J., concurring).

358. Am. Ass'N OF Univ. Professors et AL., Threats to the IndePENDENCE OF STUdent MEDIA 9 (2016), https://splc.org/wp-content/uploads/2018/08/1398_jointstatement_aaupb ulletin_studentmedia_finalo.pdf [https://perma.cc/KY2A-BAZQ]. 
What is lost when journalists are unable to have open and unfiltered communications with government employees? One consequence is that reporters become more dependent on unnamed sources, as employees seek the sanctum of anonymity to protect against supervisory retaliation. Heavily using anonymous sources has been shown to make news reports less believable, thus taking a toll on the public's already-diminished faith in the trustworthiness of news coverage. ${ }^{359}$

Where the right to speak about contemporary issues of the day is at stake, delay is itself an injury. ${ }^{360}$ As one federal judge observed in invalidating a fire department's policy requiring pre-approval from the fire chief of any statement meant for publication: "Even if the chief decided to approve every request for constitutionally-protected speech, plaintiffs would have to wait hours or even days for the permission. Even a temporary restraint on expression may constitute irreparable injury." ${ }^{361}$ As a practical matter, delay is often tantamount to a denial. If a journalist working on a time-sensitive story asks for a comment and is told, "I can't talk without going through an approval process," there is every chance the journalist will simply move on, and the employee's opportunity to address the issue will be lost.

Because Garcetti has proven so confusingly malleable, it is important to maintain the judicially recognized distinction between challenges to individual disciplinary decisions over the content of particular workrelated speech (Garcetti and Pickering) versus facial challenges to categorical prohibitions on work-related speech (NTEU). Otherwise, the Garcetti standard can easily be manipulated by employers to transform all interactions with the news media into work assignments. That is to say, if employers are allowed to filter all news media inquiries through the supervisor of public relations, and that supervisor then designates a particular agency employee to respond to the journalist, then every interview can always be characterized as an official work assignment. ${ }^{362}$

359. See, e.g., Hoyt Purvis, Anonymous Sources: More or Less and Why and Where?, $30 \mathrm{Sw}$. MAss COMMC'N J. 2, 2 (2015) (quoting veteran editors from Washington Post and Philadelphia Inquirer on their belief that over-reliance on unnamed sources erodes reader trust).

360. As Professor Jack Balkin noted, "under a system of prior restraint, communicationincluding communication of content that is completely protected under the First Amendment—cannot occur until permission is granted, which may undermine the communicative force or value of the message." Jack M. Balkin, Freedom of the Press: Old-School/New-School Speech Regulation, 127 HARV. L. REV. 2296, 2316 (2014).

361. Providence Firefighters Local 799 v. City of Providence, 26 F. Supp. 2d 350, 354-55 (D.R.I. 1998) (citation omitted).

362. This issue has already surfaced in a few employee-speech cases. In two cases, the courts cited the close supervision of the employer's public-relations department as a factor in concluding that an employee's interview with the news media was a Garcetti work assignment. Bruno v. Town of 
Forbidding employees from discussing their work with the news media invariably will fail the test of overbreadth, because a categorical prohibition cannot be shown to be necessary to advance the government's justifications. ${ }^{363}$ The rationales commonly offered to legitimize restraining employee speech include avoiding public confusion about the agency's work, and promoting a favorable public impression of the agency. ${ }^{364}$ For instance, a state university in New York directs its employees to funnel all media requests to the university's marketing department, explaining: "Our goal is to speak with one voice as an institution, with the hope of generating positive news coverage of the New Paltz campus community." 365 But even if "positive news coverage" were recognized as a legitimate objective justifying the use of governmental authority to constrain speech, a total blackout on interviews is not narrowly tailored to achieve the desired end. In many instances, the prohibition will silence entirely harmless speech that is beyond the government's legitimate authority to restrict. The employee might issue an express disclaimer that she is sharing only her unofficial personal opinion. The employee might address an issue so far afield of her job duties (for instance, the lack of adequate mass-transit options for her commute to work) that it will be obvious she is not speaking on behalf of the agency. The news organization might not even identify the employee by her workplace affiliation at all. Or the employee might say something complimentary that would actually enhance the public's confidence in the agency.

Agency interviewing policies are not narrowly tailored because they

Framingham, No. 08-cv-11403-LTS, 2009 WL 4062177, at*9 (D. Mass. Nov. 20, 2009); Almontaser v. N.Y.C. Dep't of Educ., No. 07 Civ. 10444(SHS), 2009 WL 2762699, at *3-4 (S.D.N.Y. Sept. 1, 2009).

363. See Boos v. Barry, 485 U.S. 312, 329 (1988) (explaining that a content-based restriction on speech is unconstitutional if it is not narrowly tailored and less speech-restrictive alternatives are readily available).

364. For example, the policy restricting city employees' media communications at issue in the case of Milde v. Housing Authority of Greenwich was said to be necessary "to enhance the image and public perception of the Housing Authority, its programs and residents." No. 3:00CV2423(AVC), 2006 U.S. Dist. LEXIS 62791, at *6 (D. Conn. Sept. 5, 2006) (internal quotation marks omitted). See also In re Disciplinary Action Against Gonzalez, 964 A.2d 811, 821 (N.J. Super. Ct. App. Div. 2009) ("Courts have concluded that a public employer has legitimate concerns regarding unauthorized employee communications with the press based up upon interests such as: (1) the need to maintain discipline or harmony among co-workers; (2) the need for confidentiality; (3) the need to limit conduct that impedes the public employee's proper and competent performance of his duties; and (4) the need to encourage close and personal relationships between employees and their superiors." (quoting Hall v. Mayor of Pennsauken, 422 A.2d 797, 799 (N.J. Super. Ct. App. Div. 1980)) (internal quotation marks omitted)).

365. State Univ. N.Y.-New Paltz, OfFice of Comm'N \& Mktg, Media Relations Policy, https://www.newpaltz.edu/ocm/media-relations-policy/ [https://perma.cc/D3T9-6PSJ] (last visited Oct. 24, 2019). 
treat all conversations with employees of all kinds equally, failing to account for qualitative differences in the public's need to receive information; for instance, there is no recognition of the public's heightened interest in being informed about such life-and-death functions of government as how police use their arrest authority. ${ }^{366}$ Additionally, few agency policies distinguish between on-duty and off-duty speech, conveying the impression that the employer claims authority over speech on personal time equivalent to that over speech at work during the workday. ${ }^{367}$ Nor are workplace policies tailored-as judicial gag orders commonly are - by duration, such as the length of a trial; an employee who is restricted from talking about a sensitive ongoing matter of agency business is still restricted from talking about it five years later when the sensitivity has passed. ${ }^{368}$ As shown by the relative success that employers have experienced in defending disciplinary actions for workplace speech under the rules of Connick and Garcetti, an agency has recourse to the less speech-restrictive alternative of punishing particular acts of speech afterthe-fact if they prove disloyal or disruptive. ${ }^{369}$ For all of these reasons, the gag policies commonly in force across all levels of government are insufficiently well-tailored to survive an overbreadth challenge.

Regardless of their questionable legality, employee gag policies are not just ubiquitous but unapologetically ubiquitous, their proponents seemingly unaware that a complete proscription against discussing government matters might implicate an employee's legally protected

366. Several federal courts have recognized, in the context of First Amendment claims involving the videotaping of police conducting official business in public spaces, that the public has an especially keen interest in keeping watch over the performance of critical public-safety duties. See, e.g., Glik v. Cunniffe, 655 F.3d 78, 82 (1st Cir. 2011) (noting that the need to protect the public's ability to gather information about government is "particularly true of law enforcement officials, who are granted substantial discretion that may be misused to deprive individuals of their liberties"); Fields v. City of Philadelphia, 862 F.3d 353, 359-60 (3d Cir. 2017) (citing Glik and deciding that the right to record police activity "falls squarely within the First Amendment right of access to information," noting that videos of police doing their jobs may help expose official misconduct, or conversely, exonerate the wrongfully accused).

367. Professor Mary-Rose Papandrea has proposed a two-tiered standard under which off-hours speech is recognized as more highly protected. See Mary-Rose Papandrea, The Free Speech Rights of Off-Duty Government Employees, 2010 B.Y.U. L. REV. 2117, 2164-65 (2010) (asserting that off-duty speech should be punishable only if it reveals unfitness to perform official duties or is reasonably interpreted as an official agency statement by virtue of the speaker's high-ranking position).

368. See, e.g., Journal Publ'g Co. v. Mechem, 801 F.2d 1233, 1236-37 (10th Cir. 1986) (striking down judge's order restraining media indefinitely from interviewing jurors after trial was concluded, because the order "contained no time or scope limitations and encompassed every possible juror interview situation").

369. A judge's ability to police speech that interferes with a fair trial through after-the-fact contempt sanctions was a consideration in the Illinois Supreme Court's decision to strike down a broad gag order on parties and attorneys. See Kemner v. Monsanto Co., 492 N.E.2d 1327, 1339 (Ill. 1986). 
rights. In 2018, the newly elected mayor of McComb, Mississippi, emailed everyone in his administration, including the police chief, instructing them not to speak to the local newspaper. When questioned, he flatly told the paper: "If you all want to know something, you see me. No city employee is supposed to talk to you." ${ }^{370}$ In a report on the phenomenon of public-relations gatekeeping in government agencies, the nonprofit Poynter Institute quoted one handbook popular among Capitol Hill public-relations professionals, which instructs:

It must be made clear to all staff that they should deal with the media only when authorized by the public relations team. Loss of control over communications can be a disaster for an organization, leading to public controversy and loss of credibility ....

Most organizations have policies against talking to reporters, but this is hard to enforce in a large organization. If this occurs and the person responsible makes himself known, it's best to clamp down as quickly as possible. ${ }^{371}$

The notion that employees must be restrained from saying anything to the public about their work because they might compromise the image of the government agency or undercut the message that the agency hopes to convey devalues the public's interest in an unvarnished understanding of how government works. Government is not a brand of breakfast cereal or laundry detergent. As Professors Carolyn Carlson and David Cuillier wrote, in cautioning of the dangers of increasingly aggressive intermediation by public-affairs officers:

Information critical of the government might be less likely to come to light, and citizens might be left in the dark and ill-prepared to make informed decisions at the polls. Ultimately, the United States could experience a gradual shift toward reduced press freedom and increased government propaganda endured in other nations. ${ }^{372}$

Agencies can enforce narrow restrictions on communications with the media tailored to the Pickering/Connick/Garcetti standards, including prohibiting employees from compromising confidential information or holding themselves out as official agency spokespeople without

370. Stetson Payne, Mayor: Say Nothing to Press, ENTERPRISE-J. (Aug. 28, 2018), http://www.enterprise-journal.com/news/article_69719e3e-aa4f-11e8-959e-1ba8a6bda3de.html [https://perma.cc/WM84-EEQ5].

371. Tompkins, supra note 355 (quoting BRADFORD FITCH, MEDIA RELATIONS HANDBOOK FOR GOvERnMENT, AsSOCIATIONS, NONPROFITS, AND ELECTED OFFICIALS (Jack Holt ed., 2d ed. 2012)).

372. Carlson \& Cuillier, supra note 219, at 209. 
authorization. ${ }^{373}$ If an individual speaks in an especially disruptive manner that undermines trust in the speaker's ability to perform as a public servant, the First Amendment does not foreclose imposing sanctions. That is all the authority that government should need to accomplish its legitimate objectives. Wholesale prohibitions on unapproved contact with journalists, or with the general public, have long been recognized as unconstitutional, and remain so even after Garcetti.

373. See Hanneman v. Breier, 528 F.2d 750, 754 (7th Cir. 1976) (stating that a Milwaukee Police Department policy forbidding officers from disclosing confidential information about internal investigations "is clearly valid on its face"); see also Zook v. Brown, 748 F.2d 1161, 1167-68 (7th Cir. 1984) (finding that Illinois sheriff's policy requiring pre-approval when speaking as an official representative of the department was not an overbroad restraint). 